\title{
Article \\ Dynamics of the Spatial Chlorophyll-A Distribution at the Polar Front in the Marginal Ice Zone of the Barents Sea during Spring
}

\author{
Pavel R. Makarevich, Veronika V. Vodopianova*(D) and Aleksandra S. Bulavina (D)
}

check for

updates

Citation: Makarevich, P.R.;

Vodopianova, V.V.; Bulavina, A.S

Dynamics of the Spatial Chlorophyll-A

Distribution at the Polar Front in the

Marginal Ice Zone of the Barents Sea

during Spring. Water 2022, 14, 101.

https://doi.org/10.3390/w14010101

Academic Editors: Domenico

D'Alelio, Luigi Caputi and

Maria Moustaka-Gouni

Received: 29 October 2021

Accepted: 3 January 2022

Published: 4 January 2022

Publisher's Note: MDPI stays neutral with regard to jurisdictional claims in published maps and institutional affiliations.

Copyright: (C) 2022 by the authors. Licensee MDPI, Basel, Switzerland. This article is an open access article distributed under the terms and conditions of the Creative Commons Attribution (CC BY) license (https:// creativecommons.org/licenses/by/ $4.0 /)$.

\author{
Murmansk Marine Biological Institute (MMBI), 183010 Murmansk, Russia; makarevich@mmbi.info (P.R.M.); \\ bulavina@mmbi.info (A.S.B.) \\ * Correspondence: vodopyanova@mmbi.info
}

\begin{abstract}
Effects of the sea-ice edge and the Polar Frontal Zone on the distribution of chlorophyll-a levels in the pelagic were investigated during multi-year observations in insufficiently studied and rarely navigable regions of the Barents Sea. Samples were collected at 52 sampling stations combined into 11 oceanographic transects over a Barents Sea water area north of the latitude $75^{\circ} \mathrm{N}$ during spring 2016, 2018, and 2019. The species composition, abundance and biomass of the phytoplankton community, chlorophyll-a concentrations, hydrological and hydrochemical parameters were analyzed. The annual phytoplankton evolution phase, defined as an early-spring one, was determined throughout the transects. The species composition of the phytoplankton community and low chlorophyll-a levels suggested no phytoplankton blooming in April 2016 and 2019. Not yet started sea-ice melting prevented sympagic (sea-ice-associated) algae from being released into the seawater. In May 2018, ice melting began in the eastern Barents Sea and elevated chlorophyll-a levels were recorded near the ice edge. Chlorophyll-a concentrations substantially differed in waters of different genesis, especially in areas influenced by the Polar Front. The Polar Front separated the more productive Arctic waters with a chlorophyll-a concentration of $1-5 \mathrm{mg} / \mathrm{m}^{3}$ on average from the Atlantic waters where the chlorophyll-a content was an order of magnitude lower.
\end{abstract}

Keywords: chlorophyll- $a$; Polar Front; frontal zone; ice edge; Barents Sea

\section{Introduction}

The Barents Sea lies in the area whereby the Atlantic water flux intrudes into the Arctic Ocean. About half of all Atlantic waters penetrating the Arctic Basin flow through the Barents Sea. The other part enters the Arctic Ocean directly through the Fram Strait [1]. Passing north and northeast of Svalbard, part of the Atlantic water contacting with the sea surface quickly cools and freshens through the interaction with the atmosphere and sea ice. As a result, the upper part of the Atlantic water loses its identity, transforming into a surface arctic water mass with negative temperatures and reduced salinity [2]. The Atlantic water flowing through the Barents Sea transforms more slowly. It can be traced even at the eastern border of the Barents Sea [3]. Researchers distinguish several frontal zones across the Barents Sea water area located along the pathway of Atlantic water advection into the Arctic Basin [4-7]. The Polar Frontal Zone is well traced throughout the year. It mainly separates Atlantic waters from Arctic waters.

Studying the course of the spring development of microphytoplankton and its pigment composition makes it possible to obtain a more complete picture of the seasonal succession and production of primary producers in the Barents Sea, since most of the annual biomass of the Arctic phytoplankton is produced during the spring successional cycle. The amount of chlorophyll- $a$ serves as an indicator of the productivity, abundance, and biomass of the phytoplankton community. Pelagic microalgae, major producers of organic matter in the marine environment, determine the structure and biological productivity of marine ecosystems as their main component. This fact puts great importance on the productivity of 
sea waters, particularly in poorly studied regions. Possessing a high reproduction rate and, as a result, demonstrating a quick response to changes in external conditions, planktonic assemblages are the most vulnerable to man-made and environmental factors $[8,9]$.

Phytoplankton studies are carried out both using satellite data alone [10-12] and involving data from in-situ measurements [13-17]. In-situ data from hydrological and phytoplankton investigations for the northern Barents Sea areas located north of the latitude $75^{\circ} \mathrm{N}$ are limited because these areas are hardly navigable since they are covered with ice for most of the year. Phytoplankton studies north of $75^{\circ} \mathrm{N}$ are described in [13-17]. Most of the studies were conducted in the western Barents Sea.

Seawater thermohaline characteristics and migration routes may have impacts on the development of the phytoplankton community [13-15]. Thus, as stated in [14], "different mixing regimes in Atlantic waters, Polar Front region and the Arctic water region are structured by different stratification mechanisms which has implication for the phytoplankton community development and the new production". Phytoplankton studies in the Marginal Ice Zone are of particular interest for researchers because this area represents a unique habitat for two groups of primary producers tightly linked to each other, pelagic and ice flora, which form the basis for the production of the primary organic matter in the Barents Sea [18,19].

The influence of the ice edge on phytoplankton and the distribution of chlorophyll- $a$ concentrations is discussed in [10]. Using satellite data, the authors showed that the iceedge bloom occurs in all seasonally ice-covered regions from spring to late summer and usually reaches its maximum during 20 days after the ice retreat. Sometimes these blooms form stretched belts along the ice edge as long as $100 \mathrm{~km}$ and more, although smaller structures are also observed. They are usually, though not always, located close to the ice edge and peak on average at $>1 \mathrm{mg} / \mathrm{m}^{3}$ chlorophyll- $a$, with larger blooms peaking at $>10 \mathrm{mg} / \mathrm{m}^{3}$ chlorophyll- $a$. Some of them follow the retreating ice edge for hundreds of kilometers and for several months while others remain stationary. Using satellite data, [11] reported the spring phytoplankton bloom in the northern Barents Sea to start earlier and produce greater values of chlorophyll- $a$ in the warmer years compared to the colder ones, but no appreciable correlation was observed in the southern Barents Sea. In seasonally ice-covered regions, the timing of the sea ice retreat before mid-May was shown not to be tied to the timing of the bloom, while after mid-May the phytoplankton bloom was reported to occur before or immediately after the sea ice retreat. Based on satellite and in-situ data, [12] pointed out the surface chlorophyll to be a good predictor of relative levels of the phytoplankton total biomass during spring. The highest chlorophyll- $a$ concentrations were observed at the ice edge and then decreased further into the ice. The chlorophyll- $a$ observations indicated a strong primary bloom about 2 weeks after the ice edge had receded from the measurement location. Signs of several minor blooms were also reported to be observed about 2 weeks after the initial bloom.

Questions about the timing of the onset of the phytoplankton spring bloom, its duration and causes in northern Barents Sea regions still remain open. We have made an attempt to assess the differences in the chlorophyll- $a$ content in water masses that have different origins. The high latitudinal position of retreated sea ice during our investigations in spring 2016, 2018, and 2019 gave us opportunity to acquire important data from poorly studied areas of the Barents Sea $\left(75^{\circ}-79^{\circ} \mathrm{N}\right.$ in the zone of the ice-edge influence and in frontal zones) rarely navigable during this time of the year.

Preliminary results of this study were reported at the International Applied Research Conference «BRDEM-2019» and published in the conference collection of papers [20]. Ref [20] describes differences in chlorophyll- $a$ levels in different Barents Sea water masses, although the factors that cause these differences were not discussed. Later on, additional data on the species composition of phytoplankton assemblages and the seawater hydrology during the investigation period were acquired. In the present paper, chlorophyll- $a$ concentrations are discussed in the light of these additional data. This helped us define the phytoplankton annual evolution phase in the investigated regions of the Barents Sea 
and provide a more detailed description of the pelagic system near the sea-ice edge and in Barents Sea frontal zones.

\section{Materials and Methods}

Water samples collected during 3 cruises on the $\mathrm{r} / \mathrm{v}$ "Dalnie Zelentsy" to the northern Barents Sea in April and May 2016, 2018, and 2019 served as the material for this study (Figure 1). These cruises consisted of 11 oceanographic transects encompassing a total of 52 sampling stations investigated under tough ice conditions. Water mass temperature and salinity were measured using an SBE 19 plus CTD sonde. To identify water masses and determine their boundaries, a gradient method and classical T-S analysis were used [21]. The values of the horizontal temperature and salinity gradients, 5 times as high as the climatic gradients for the Barents Sea $\left(0.01{ }^{\circ} \mathrm{C} / \mathrm{km}\right.$ and $0.001 \%$ o $\left./ \mathrm{km}\right)$ [22], were taken as a criterion for the presence of a frontal zone on the sea surface.

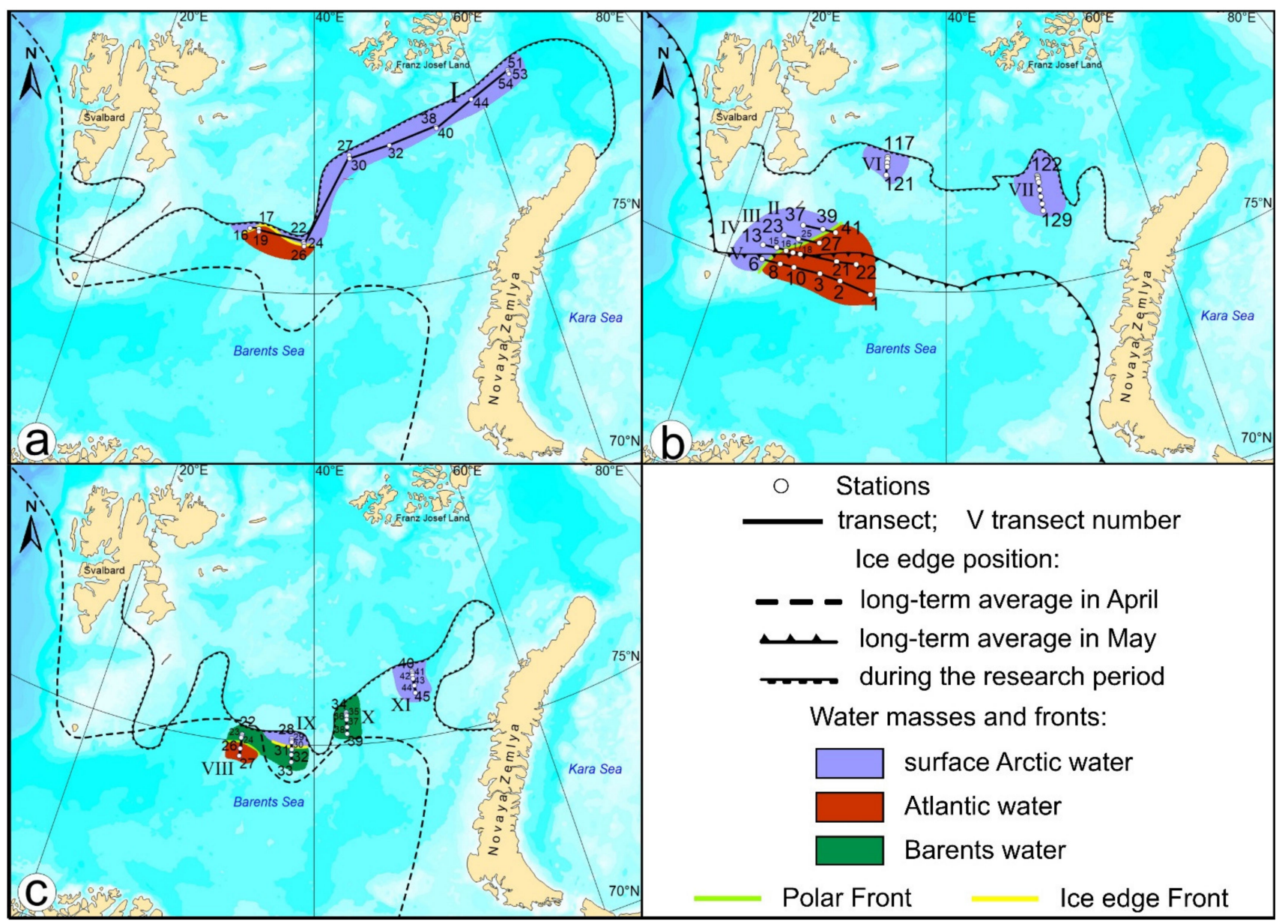

Figure 1. Location of investigated transects and sampling stations and sea ice conditions during the investigations. (a) -2016; (b) -2018; (c) -2019.

Nutrient $\left(\mathrm{P}-\mathrm{PO}_{4}\right.$ and $\left.\mathrm{N}-\mathrm{NO}_{3}\right)$ concentrations were measured using standard methodology $[23,24]$. Chlorophyll-a samples and samples for phytoplankton taxonomy were collected with a 10-L Hydro-Bios (Kiel, Germany) water sampler from several horizons at depths of $0,10,25$, and $50 \mathrm{~m}$. Seawater samples were filtered for pigment content onboard on a vacuum filtration apparatus equipped with a GAST vacuum pump, using 47-mm diameter $0.6-\mu \mathrm{m}$ pore size membrane filters. Chlorophyll- $a$ concentrations were determined spectrophotometrically $[25,26]$ on a Nicolett Evolution 500 ultraviolet-visible spectrophotometer (Spectronic Unicam, UK). 
To determine the stage of seasonal development of phytoplankton, the taxonomic composition of the phytoplankton community was analyzed. Then, 1-liter water samples for the taxonomy analysis were concentrated by the reverse filtration method [27] through $0.95-\mu \mathrm{m}$ pore size lavsan polyester fiber filters and fixed with neutral buffered formalin to a final concentration of $1 \%$. Identification of the species composition of microalgae was carried out using a Carl Zeiss Axio Imager D1 microscope at a magnification of $400 \times$. Species' biovolumes (as $\mu \mathrm{m}^{3}$ cell $^{-1}$ ) were calculated from assigned geometric shape [28].

\section{Results}

Transect I was investigated in April 2016 in the vicinity of the ice edge (Figure 1a). Ice conditions at Transect I were presented by slush, young and first-year ice according to data on the ice situation in the area and our own observations.

Stations 16, 17, 19, 22, 24, and 25 of transect I were located in a near-edge frontal zone. The maximum horizontal temperature and salinity gradients on the sea surface, exceeding the climatic ones, were determined between stations 16 and 17 and 24 and 25, indicating the presence of a front between these stations. Stations 16, 22 and 24 were located in the zone of influence of surface Arctic water with negative temperatures and low salinity. At these stations, Arctic water extended down to depths of 50-75 m, below was Atlantic water. At stations 25, 17, and 19 the whole water column was occupied by Atlantic water with positive temperature and high salinity. At stations 27-54 of transect I, depths of 50-100 m were dominated by Arctic water underlain by Barents water. Besides, an Atlantic water flux was registered at 100-150 m depth at stations 51-54 (Appendix A, Figures A1 and A2).

The near-edge front influenced the distribution of chlorophyll- $a$ in the studied water area. The highest chlorophyll content at Transect I was recorded in surface Arctic water (Figure 2 and Appendix B, Table A1). In Arctic water chlorophyll-a concentration was 2 times as high as in Atlantic water. The distribution of chlorophyll in the 0-50 m layer was fairly uniform.

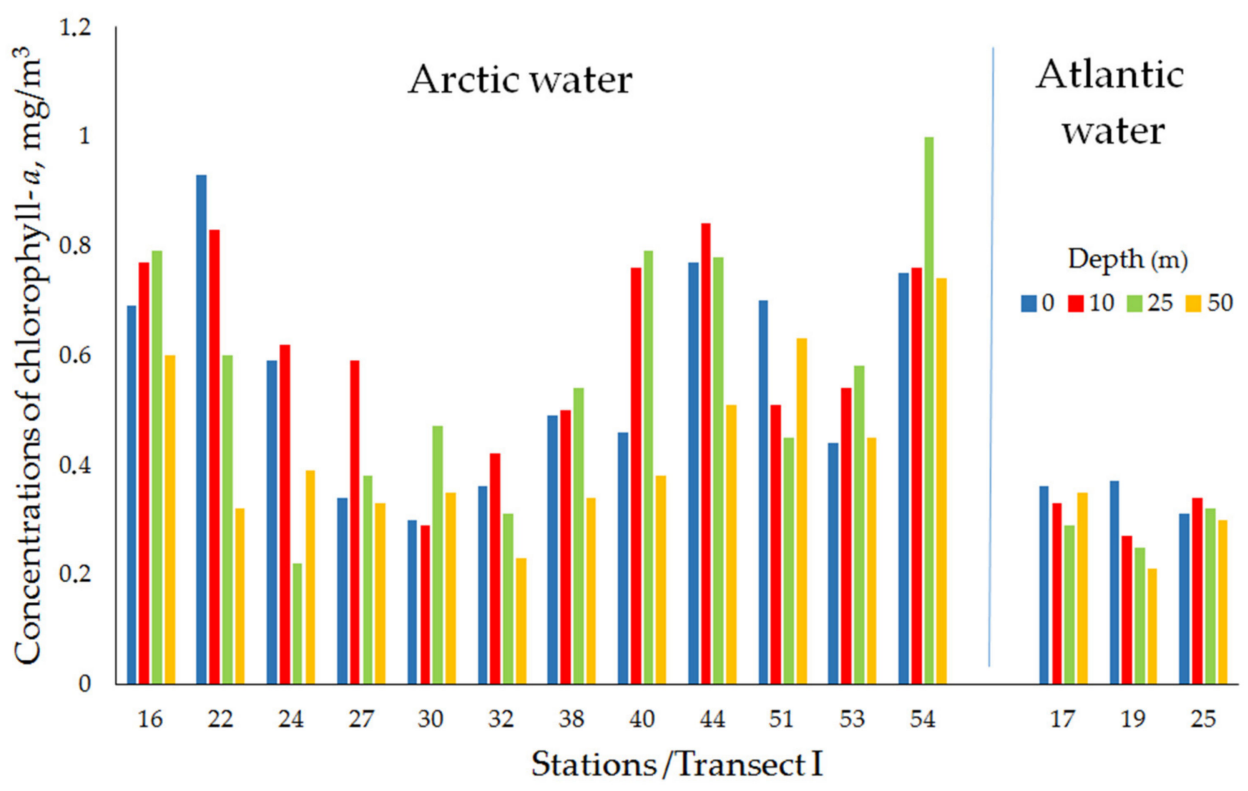

Figure 2. Concentrations of chlorophyll- $a\left(\mathrm{mg} / \mathrm{m}^{3}\right)$ at Transect I, 2016.

Diatoms and dinoflagellates dominated the taxonomic structure of the pelagic spring phytoplankton in the Marginal Ice Zone in the Barents Sea in 2016, by 55\% and $40 \%$, respectively. The most prominent phytoplankton species among diatoms were of the genera Chaetoceros, Thalassiosira, and Navicula, and dinoflagellates were most widely presented by taxa of the genera Protoperidinium and Dinophysis. Diatoms dominated the total biomass of the microalgal community by about $90 \%$ over the entire water area, constituting a single pelagic algal assemblage in a state typical for the early spring phase of the successional cycle 
in both the Arctic and Atlantic water masses [15,17]. Figure 3 presents the phytoplankton community structure in the Barents Sea Marginal Ice Zone in April 2016. Porosira glacialis and Navicula pelagica were undeniable leaders in the biomass production making up to $50 \%$ of the total biomass.

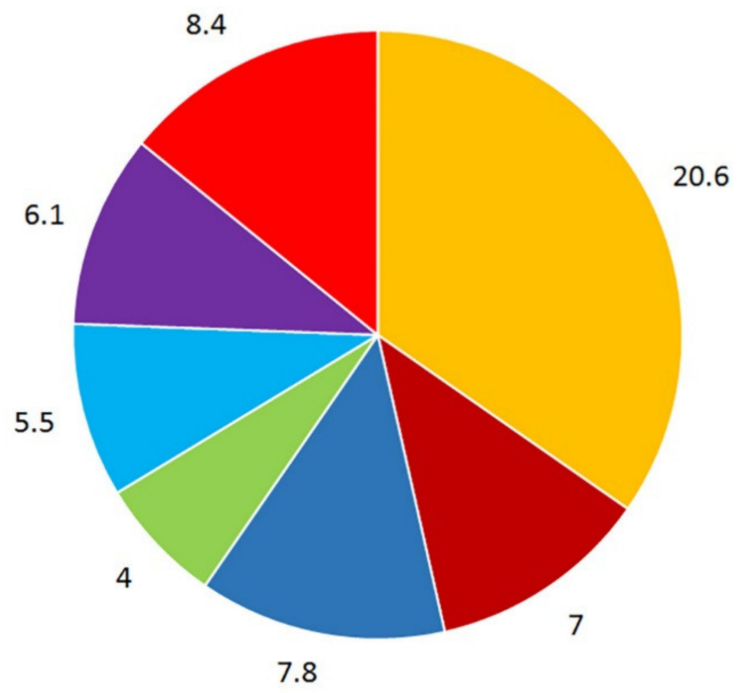

\author{
- Porosira glacialis \\ - Pennatophyceae spp. \\ - Thalassiosira antarctica \\ - Chaetoceros socialis \\ - Thalassiosira hyalina aff. \\ - Phaeocystis pouchetii \\ - Navicula pelagica
}

Figure 3. Biomass $(\mu \mathrm{g} / \mathrm{L})$ of the dominant pelagic microalgae species, averaged for the stations and seawater levels in the Barents Sea Marginal Ice Zone in April 2016.

Phytoplankton investigations at transects II, III, IV, and V (Figure 1b) in April 2018 were carried out over a slope of the Spitsbergen Bank where, according to [6,29,30], the Polar Front is quasi-stationary located. The study area included 19 stations located between the latitudes $74.8^{\circ}$ and $76.2^{\circ} \mathrm{N}$ and the longitudes $23^{\circ}$ and $33.3^{\circ} \mathrm{E}$.

The Polar Front separated Arctic water from water of Atlantic origin. The frontal zone was shifted from its long-term average position, which is typical for modern climatic variations [30,31]. The western stations of these 4 transects (St. 37, 39, 23, 25, 13, 15, and 5) were situated in Arctic waters and the eastern stations at the study site (St. 41, 27, 16, 17, 18, $21,22,8,10,3,2$, and 1) were allocated in the Atlantic water mass (Appendix A, Figure A3).

The highest concentrations of chlorophyll- $a$ were recorded at transects II and III with maxima at the stations located near the ice edge in Arctic waters. The average chlorophyll- $a$ content varied in the range of $2-5 \mathrm{mg} / \mathrm{m}^{3}$ and was distributed evenly in the 0-50 m layer (Figure 4 and Appendix B, Table A1). At transects IV and V, the maximum chlorophyll concentrations were also recorded in Arctic waters. In the 0-10 m layer, the average chlorophyll- $a$ content ranged from 2.5 to $3.8 \mathrm{mg} / \mathrm{m}^{3}$, decreasing with depth to $<1 \mathrm{mg} / \mathrm{m}^{3}$. In the Atlantic waters the average concentration of chlorophyll- $a$ was $<1 \mathrm{mg} / \mathrm{m}^{3}$ at all transects. Thus, the Polar Front acted as a boundary that separated Arctic water with the highest chlorophyll- $a$ content from Atlantic water where the chlorophyll- $a$ concentrations were an order of magnitude lower.

In May 2018, the material for the investigation was sampled in the zone of influence of the ice edge, at transects VI and VII (Figure 1b). At transect VI, a layer of Arctic water was underlain by Atlantic water. Between surface Arctic water and Atlantic water, a vast density-jump layer about $100 \mathrm{~m}$ in depth was observed, whose temperature and salinity monotonously increased with depth. At transect VII, Barents water was registered under a layer of Arctic water. The boundary between the layers at transect VII was more contrasted than it was at transect VI, suggesting the onset of the ice melt in this region. Although no complete layer of melt water had yet formed by the time of the investigations. At all stations of transects VI and VII, the 0-50 m layer, from which chlorophyll samples were collected, was dominated by Arctic water (Appendix A, Figure A4). The average concentrations of chlorophyll- $a$ in the 0-50 m layer at transect VI ranged from 1 to $2 \mathrm{mg} / \mathrm{m}^{3}$ and at transect VII varied in the range of $2-4 \mathrm{mg} / \mathrm{m}^{3}$ (Figure 5 and Appendix B, Table A1). A significant 
difference (by a factor of 2) in the chlorophyll content at the transects might have been caused by their location and the onset of a spring ice-edge bloom in the eastern part of the water area under study. Increased values of chlorophyll- $a$ were reported in [32] for the southeastern Barents Sea where a massive development of phytoplankton bloom with chlorophyll concentrations of up to $6 \mathrm{mg} / \mathrm{m}^{3}$ was observed along the ice edge during the spring period.
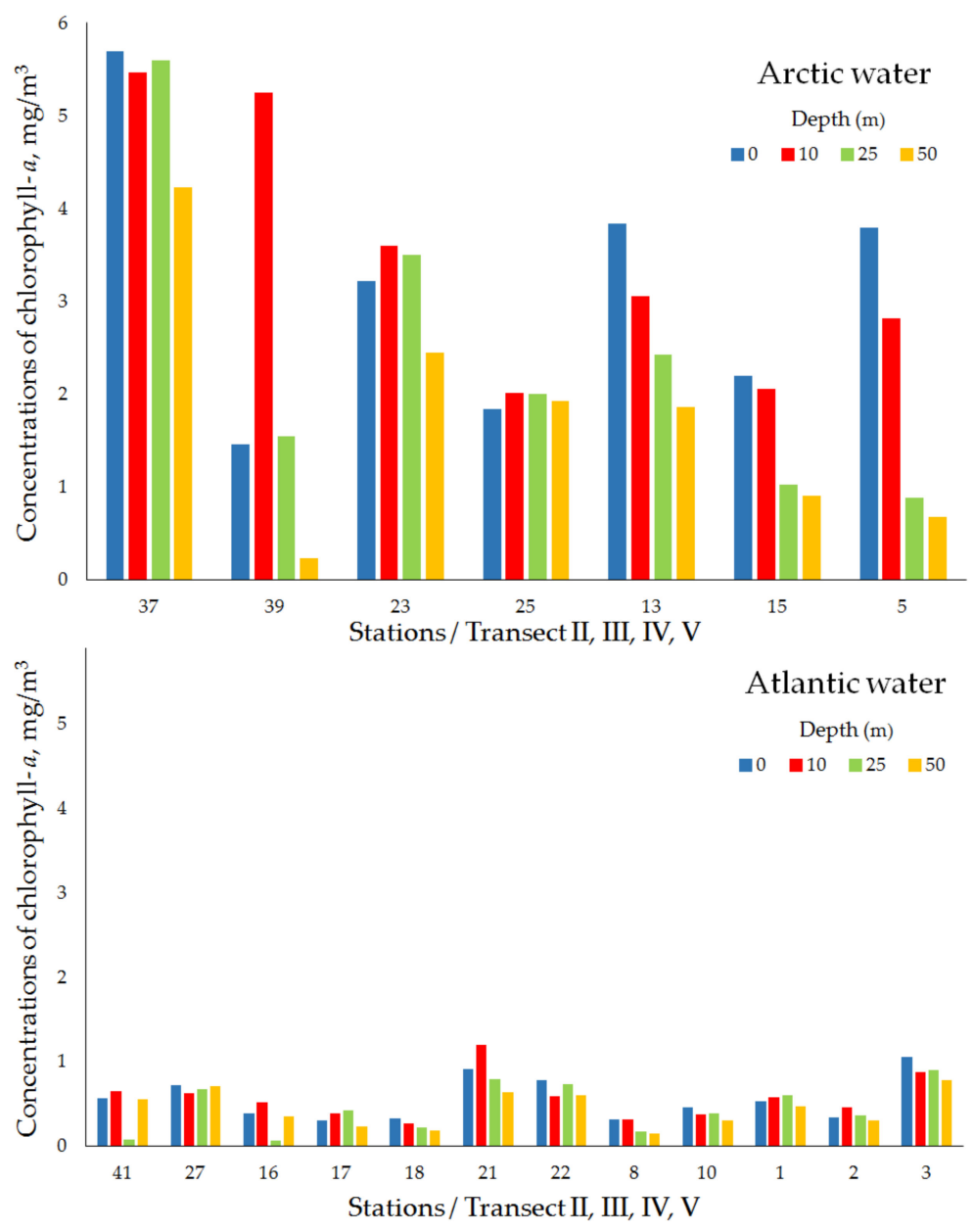

Figure 4. Concentrations of chlorophyll- $a\left(\mathrm{mg} / \mathrm{m}^{3}\right)$ at Transects II, III, IV and V, 2018.

In spring 2018, planktonic microalgal communities were dominated by early-spring groups of species throughout the studied water area, in terms of the taxonomic composition and set of dominants in each group $[15,17]$. Diatomic algae typical for the given season, representatives of the genera Thalassiosira, Chaetoceros, Navicula, and Pseudo-nitzschia, completely dominated in the pelagic. Beside diatoms, dinoflagellates demonstrated a high taxonomic diversity, with the genus Protoperidinium standing out with high abundance, making up almost half of the taxa. Figure 6 presents the phytoplankton community structure in terms of the dominant species' biomass averaged for the stations and seawater levels investigated in the Barents Sea Marginal Ice Zone in April and May 2018.

In April 2019, the ice-edge transects VIII, IX, X, and XI were investigated (Figure 1c). Transect VIII was located in the Polar Frontal Zone. The influence of warm surface Atlantic currents was traced at the southern stations of transect VIII and weakened when moving north. At stations 26 and 27, at depths of 65 and $115 \mathrm{~m}$, respectively, lay a thermocline dividing warm Atlantic water from the underlying Barents Sea water. At stations 22, 23, and 24 located in the northern part of transect VIII, the water column was homogeneous and had characteristics corresponding to the Barents Sea water mass. The calculation of the 
maximum horizontal temperature gradients made it possible to determine the position of the Polar Front on the sea surface (Appendix A, Figure A5).
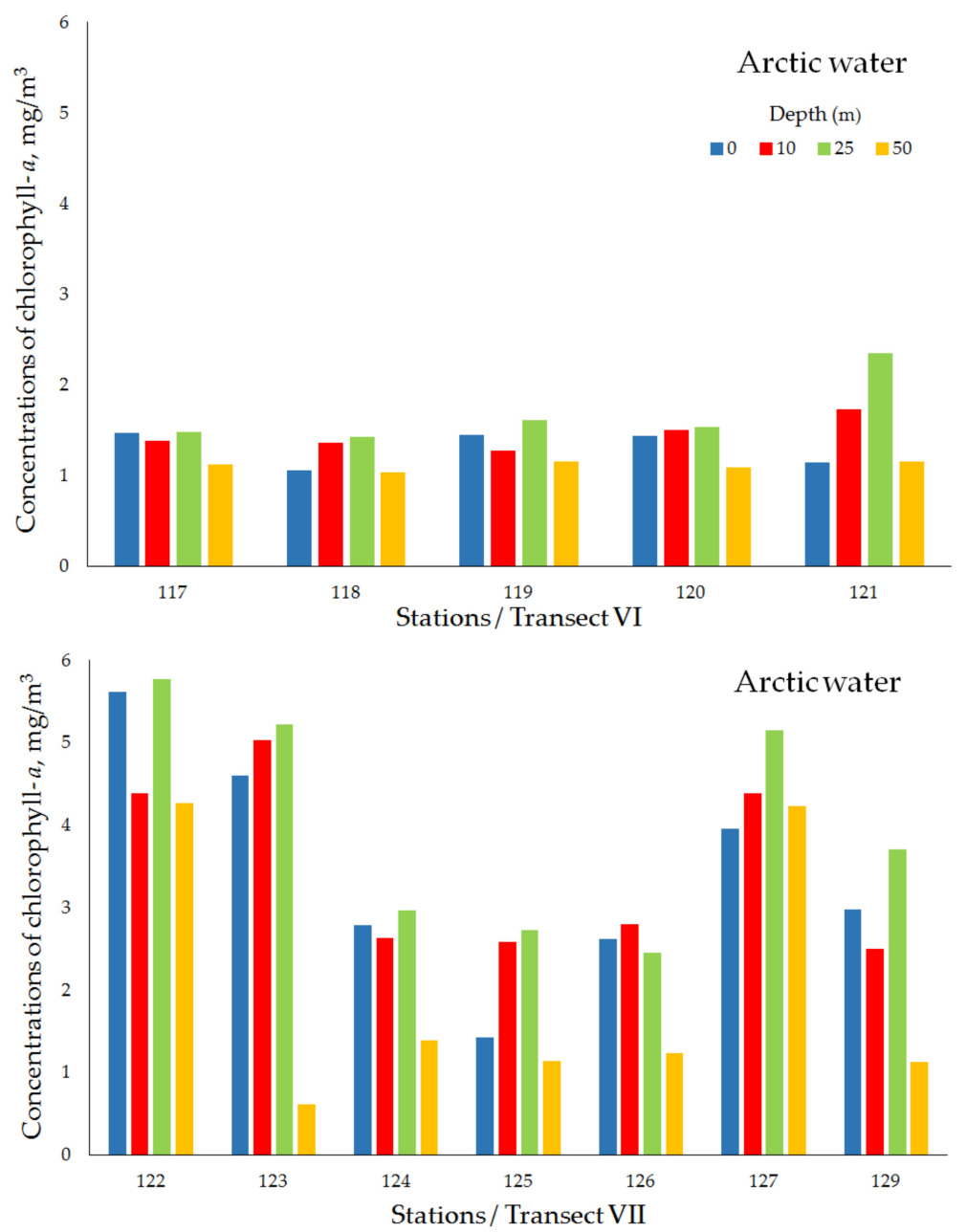

Figure 5. Concentrations of chlorophyll- $a\left(\mathrm{mg} / \mathrm{m}^{3}\right)$ at Transects VI and VII, 2018.

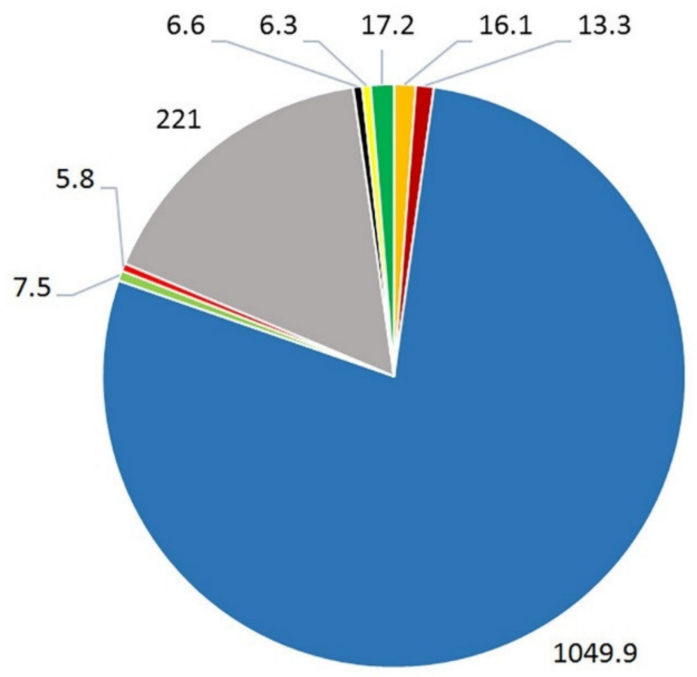

- Porosira glacialis

- Pennatophyceae spp.

- Thalassiosira antarctica

- Chaetoceros socialis

- Navicula pelagica

- Fragilariopsis oceanica

- Chaetoceros fragilis

Gyrosigma fasciola

- Pseudo-nitzschia seriata

Figure 6. Biomass $(\mu \mathrm{g} / \mathrm{L})$ of the dominant pelagic microalgae species, averaged for the stations and seawater levels in the Barents Sea Marginal Ice Zone in April and May 2018. 
The front passed between stations 24 and 26 and divided Barents Sea water where the chlorophyll- $a$ concentration was about $0.2 \mathrm{mg} / \mathrm{m}^{3}$ from Atlantic water with the chlorophylla concentration of $0.1 \mathrm{mg} / \mathrm{m}^{3}$ (Figure 7 and Appendix B, Table A1).
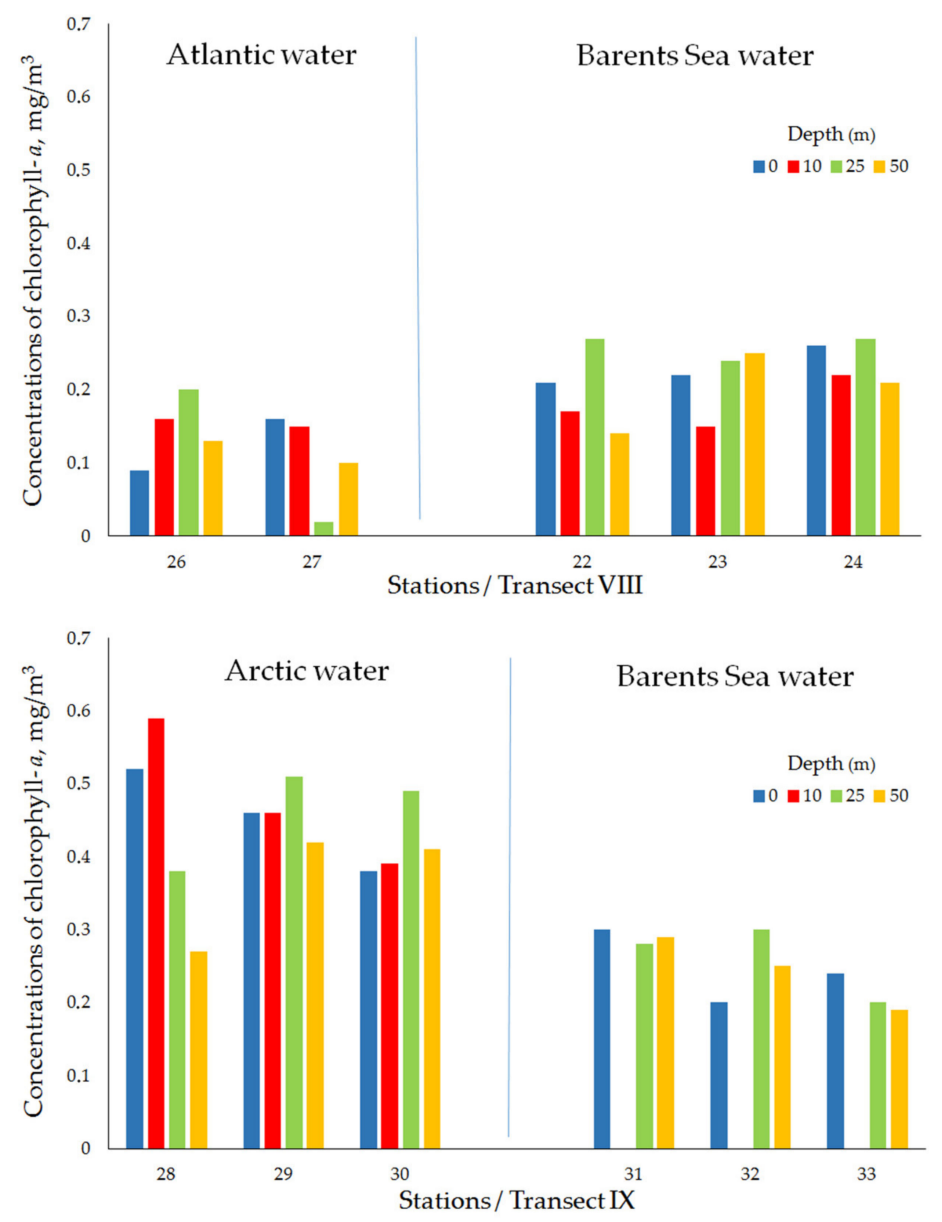

Figure 7. Concentrations of chlorophyll- $a\left(\mathrm{mg} / \mathrm{m}^{3}\right)$ at Transects VIII and IX, 2019.

At Transect IX, a difference in the structure of the water column between the northern (St. 28, 29, and 30) and southern (St. 31, 32, and 33) stations was observed. At the southern stations 32 and 33, seawater was well mixed surface to bottom. At station 31, seawater was also well mixed, but had a slightly lower temperature at the same salinity values. At the northern stations, located in close proximity to the ice edge, cold freshened Arctic water lay on the surface. Below that was Barents Sea water. Between stations 30 and 31, a near-edge front was determined on the sea surface, expressed both in terms of temperature and salinity (Appendix A, Figure A5). The near-edge front divided Arctic water with an average chlorophyll concentration of $0.4 \mathrm{mg} / \mathrm{m}^{3}$ from Barents Sea water where the chlorophyll content was about $0.2 \mathrm{mg} / \mathrm{m}^{3}$ (Figure 7 and Appendix B, Table A1).

By Transect X, stratification ceased to be traced, and at stations 34-39 the water column was homogeneous from surface to bottom and occupied by Barents Sea water (Appendix A, Figure A6). The chlorophyll concentration in Barents Sea water was about $0.2 \mathrm{mg} / \mathrm{m}^{3}$ (Figure 8 and Appendix B, Table A1). At all stations of Transect XI surface Arctic water spread down to depths of 75-120 m, underlain by Barents Sea water (Appendix A, Figure A6). The average chlorophyll concentration in Arctic water was low and varied in an insignificant range of $0.2-0.3 \mathrm{mg} / \mathrm{m}^{3}$ (Figure 8 and Appendix B, Table A1).

During the investigation in spring 2019, approximately 70 species of planktonic microalgae were recorded in the ice edge in the northeast of the Barents Sea, which mostly belonged to diatoms (about 50\%) and dinoflagellates (42\%). At the same time, early-spring 
centric and pennate diatoms of the genera Thalassiosira, Chaetoceros, and Achnanthes numerically accounted for up to $90 \%$ of the community. The bulk of diatoms were confined to the upper 5-m layer in the area of drifting ice, while dinoflagellates were distributed relatively evenly in the water column. Figure 9 presents the phytoplankton community structure in terms of the dominant species' biomass averaged for the stations and seawater levels investigated in the Barents Sea Marginal Ice Zone in April 2019.
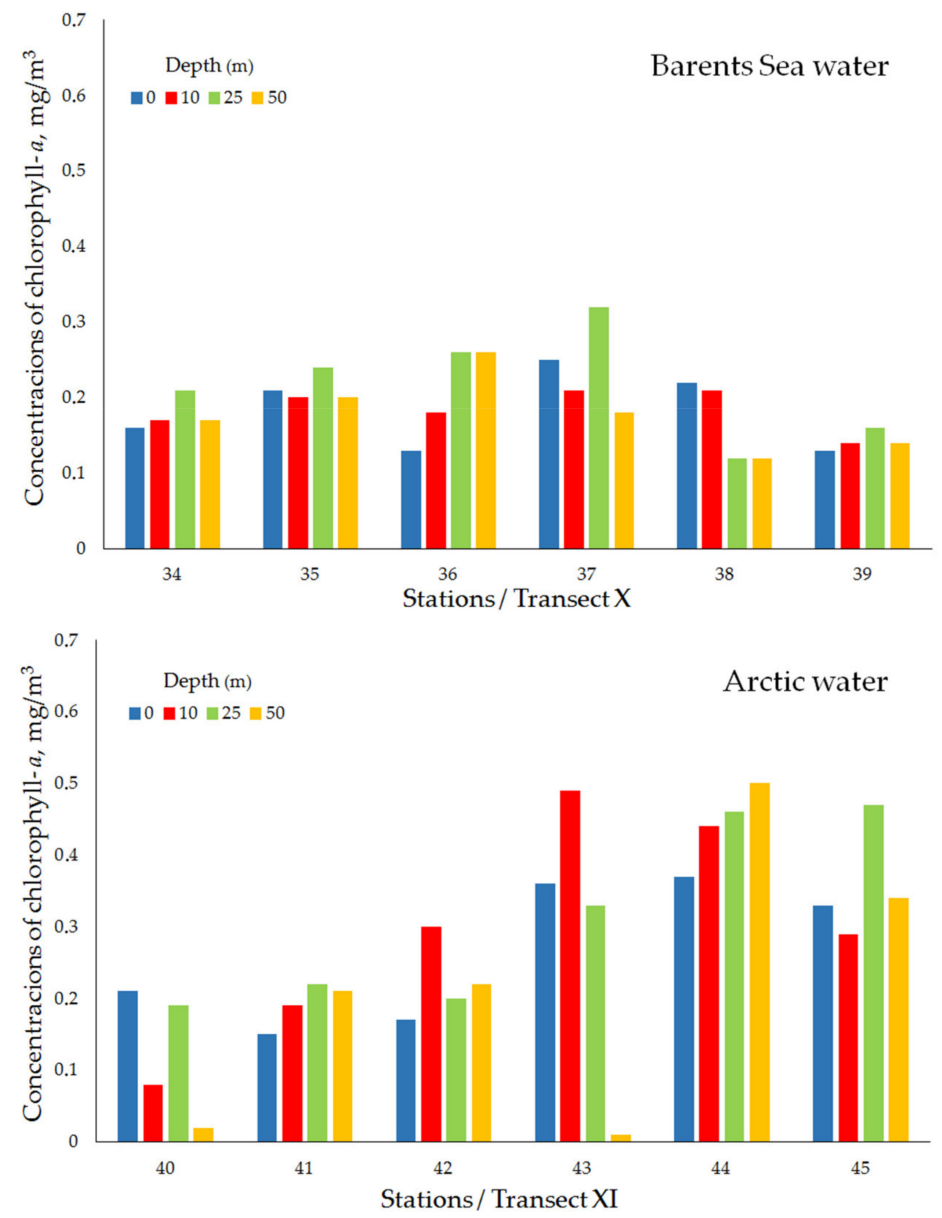

Figure 8. Concentrations of chlorophyll- $a\left(\mathrm{mg} / \mathrm{m}^{3}\right)$ at Transects X and XI, 2019.

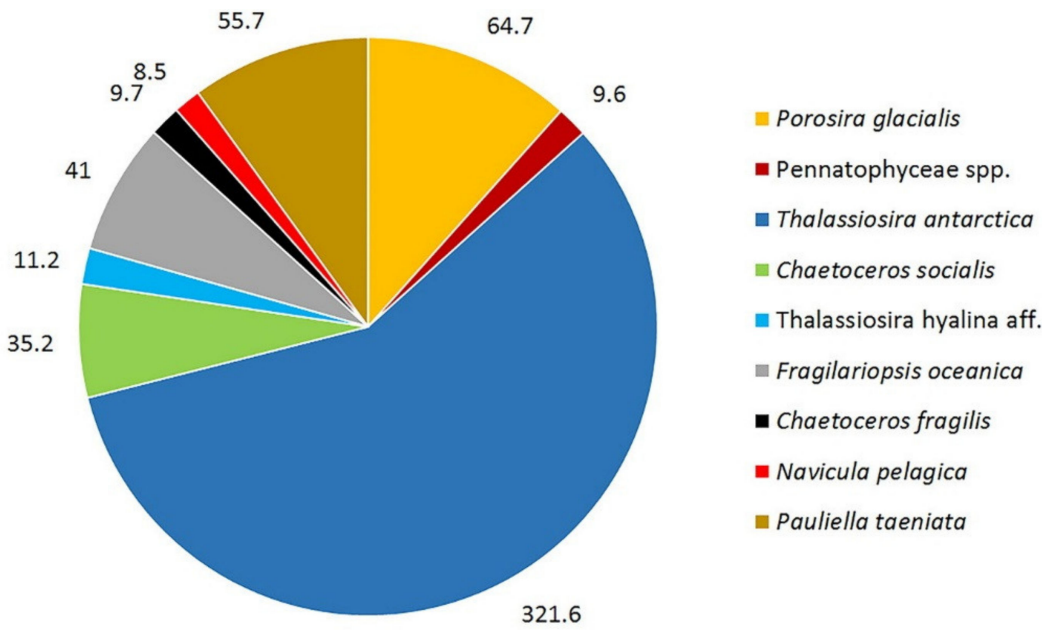

Figure 9. Biomass $(\mu \mathrm{g} / \mathrm{L})$ of the dominant pelagic microalgae species, averaged for the stations and seawater levels in the Barents Sea Marginal Ice Zone in April 2019. 


\section{Discussion}

In recent years, large negative ice coverage anomalies have been observed in the Barents Sea [33-37]. In 2016, the ice edge in the eastern Barents Sea retreated northward to $79^{\circ} \mathrm{N}$. According to Arctic and Antarctic Research Institute sea-ice concentration maps (http://www.aari.ru/odata/_d0015.php; accessed on 26 November 2021), such a northern position of the ice edge in the eastern Barents Sea in April has not been observed since 1997. We do not have earlier data on the ice history for the east of the Barents Sea. In the western part of the Barents Sea in 2016, the ice edge was located farther south of its usual position, protruding along the western boundary of the sea practically down to Bear Island. Such a location of the ice edge is not typical for the Barents Sea. Due to the powerful warming effect of Atlantic water in the west, sea ice usually retreats northward faster in the western Barents Sea than in its eastern part. During our investigations in 2018, the ice edge was also located much farther north of its average long-term position at this time of the year. Over the whole water area, it was located mainly in the latitudinal direction between $77^{\circ}$ and $78^{\circ} \mathrm{N}$ and only near the Novaya Zemlya Archipelago did it reach $75.5^{\circ} \mathrm{N}$. The year 2019 was icier than several previous years, however negative sea ice extent anomalies were also observed. The ice edge crossed the parallel $75^{\circ} \mathrm{N}$ at several locations, both in the west and in the east of the sea.

The distribution of chlorophyll- $a$ concentrations in the studied water area was mostly affected by the Polar Front. Its influence was most discernible at those transects where the front line passed between Arctic and Atlantic water masses. Atlantic waters were characterized by low chlorophyll concentrations of $0.1-0.7 \mathrm{mg} / \mathrm{m}^{3}$. The chlorophyll content in Arctic water exceeded that in Atlantic water by an order of magnitude at almost all transects. The average chlorophyll concentration at the Polar Front in the Arctic water mass varied in the range of $1-5 \mathrm{mg} / \mathrm{m}^{3}$. The values we acquired are consistent with the existing literature data. Thus, [15] reported chlorophyll- $a$ concentrations less than $1 \mathrm{mg} / \mathrm{m}^{3}$ for Atlantic waters and 1-5 mg/m $\mathrm{m}^{3}$ for Arctic waters in May 1993 in the northeastern and central Barents Sea.

Elevated concentrations of chlorophyll and phytoplankton biomass were observed along the entire ice edge throughout the studied water area, i.e., the entire Marginal Ice Zone was covered by phytoplankton vegetation. However, intensive blooming did not take place along the entire ice edge, but had a patchiness-like manner, developing in those limited areas which exhibited favorable hydrological and hydrochemical conditions. In general, the distribution of chlorophyll, similar to the distribution of phytoplankton biomass, clearly demonstrated a decrease in values with distance from the ice edge.

The vertical distribution of chlorophyll in the water column in the upper $50 \mathrm{~m}$ layer was not homogeneous. In the Marginal Ice Zone, chlorophyll maxima can be localized at different depths between years, but, as a rule, the surface $0-10$ m layer is the most productive. No homogeneity in the form of stable high chlorophyll levels were observed, i.e., a patchiness-like distribution occurred.

In May 2018, we observed the onset of spring phytoplankton bloom at the eastern transect (VII) where the chlorophyll concentration reached about $4 \mathrm{mg} / \mathrm{m}^{3}$, which was 2 times as high as the chlorophyll values at the western transect (VI). As reported in [32], elevated values of chlorophyll- $a$ were observed in the southeastern part of the Barents Sea where a massive phytoplankton bloom developed along the ice edge in spring, with chlorophyll concentrations of up to $6 \mathrm{mg} / \mathrm{m}^{3}$. Ice-edge bloom, as a phenomenon, is a very short-term process. According to remote sensing data, the active phase at each specific location lasts no longer than 5-6 days [10]. The data obtained within the same successional cycle, but from different sampling locations along the ice edge, can differ significantly and reflect the complicated spatio-temporal organization of the edge bloom. Thus, according to [12], in May 1999, chlorophyll concentrations in the surface layer at sites located at a distance of only a few kilometers from each other differed by an order of magnitude, and the phytoplankton community was at different stages of the successional cycle. The central and northern parts of the Barents Sea are known to exhibit one spring maximum of 
phytoplankton bloom, and the bulk of the annual biomass of Arctic microphytoplankton is precisely produced during the spring successional cycle. Maximum chlorophyll values during the spring period can reach, according to different authors, about $13 \mathrm{mg} / \mathrm{m}^{3}$ in the northwestern Barents Sea, about $14 \mathrm{mg} / \mathrm{m}^{3}$ during a sub-ice microalgae bloom in the central Barents Sea, and up to $10.6 \pm 1.5 \mathrm{mg} / \mathrm{m}^{3}$ in the northern Barents Sea in the Marginal Ice Zone and further into ice fields [13,14,16,32]. We did not register such high concentrations of chlorophyll- $a$ during our investigations, for we probably observed only the start of the spring bloom which had not yet reached its culmination.

The phytoplankton development produces effects on the seawater hydrochemistry. The spatial distribution of concentrations of such important biogenic elements as phosphorus and nitrogen in the Barents Sea has its own peculiarities. The hydrochemical regime of the Barents Sea pelagic during spring is described in detail in [38]. In January/February, surface phosphate concentrations constitute 0.6-0.9 $\mu \mathrm{M}$ decreasing from west to east and from north to south. At the bottom, mean annual phosphate concentrations range from 0.7 to $1.05 \mu \mathrm{M}$. Intensive consumption of phosphate begins in March-April as it gets included in production processes. The dynamics of the phosphate content in the surface 20-30 m layer is clearly seasonal in nature. As stated in [38], the phosphate content in the Arctic waters during the pre-spring period is somewhat lower than in Atlantic waters. Nitrates exhibit the same annual temporal and spatial variability as phosphates. In winter, Atlantic waters advected into the Barents Sea contain 6-7 $\mu \mathrm{M}$ of surface nitrate nitrogen, and the concertation of bottom nitrate nitrogen is $8-9 \mu \mathrm{M}$. The spring development of phytoplankton causes a noticeable decrease in surface nitrate concentrations down to $4 \mu \mathrm{M}$. The summer nitrate content in the upper 20-30 m seawater layer is characterized by low concentrations, close to the trace values, while the bottom content of bottom nitrate nitrogen is $12 \mu \mathrm{M}$. The most active assimilation of phosphates and nitrates occurs in the surface $30 \mathrm{~m}$ layer. In deeper waters, below about 50-60 m depth, a sharp increase in concentration is observed.

The results of our studies on the spatial distribution of nutrient concentrations in 2018 and 2019 (Tables A2 and A3) reveal the following features. In 2018, phosphate concentrations tended to increase with depth. Nitrate had its maximum at $100 \mathrm{~m}$ depth. The phosphate distribution in 2019 was relatively homogenous throughout the entire water column, with minimum values at $25 \mathrm{~m}$ depth. Nitrate in 2019 exhibited increased concentrations on the surface and at $100 \mathrm{~m}$ depth.

A comparative analysis of nutrient concentrations in 2018 and 2019 showed that their surface values were higher in 2019 than in 2018. This can be explained by a higher phytoplankton photosynthetic activity in 2018, i.e., by higher phytoplankton abundance and biomass (see Figures 8 and 9). Low phosphate and nitrate concentrations are usually a result of their consumption by phytoplankton [39]. Though the phosphate concentration in areas under study in 2018 and 2019 had low values throughout the water column investigated (Appendix C, Tables A2 and A3), it did not fall below $0.14 \mu \mathrm{M}$; however, during the spring bloom peak it can drop to almost 0 level. The similar picture was observed for the distribution of nitrate in the pelagic; it levels were lower than the general winter values, but higher than the values during the peak of the bloom [38]. The above-described situation confirms our inference on that, during our observations, the phytoplankton community was in a state corresponding to the initial stage of the spring vegetation.

It is known that the phytoplankton community is influenced by the availability of basic nutrients, on the one hand, and the grazing by zooplankton, on the other. Accordingly, a change in one factor or another will be followed by a change in the production characteristics of phytoplankton. An increase in water temperature and shifts in the spatial structure and timing of ice algae and phytoplankton bloom affect the phenology, magnitude, and duration of zooplankton production, with corresponding changes in the zooplankton community composition [40]. Changes in sea ice cover and thickness may also change the phenology, abundance, and distribution of zooplankton in the future. At the southern borders of the Arctic, such as the southeastern part of the Bering Sea, warm conditions 
have already led to a decrease in the production of large copepods and euphausiids. On the northern shelves (Chukchi Sea), an increase in the open water period led to an increase in the abundance of large copepods over a 60-year period, while in the Central Basins, the biomass of zooplankton as a whole increased [40]. In recent decades, the Barents Sea has witnessed an increase in the open water period [33] and a general warming trend, associated with an increase in the influx of Atlantic waters. These phenomena affect the entire pelagic system - the primary production of microalgae increases, the growth, and reproduction of zooplankton organisms accelerates, and the total biomass of zooplankton increases [41,42]. At the same time, a tendency for an increase in production characteristics with water temperature decrease was revealed [43] - the greatest contribution to the biomass and production of the entire zooplankton community in the Barents Sea is made by Arctic communities (large cold-water species form the largest biomass and production within the Arctic water mass). According to the literature, the northern regions dominated by Arctic zooplankton communities are among the most productive areas of the Barents Sea [42]. It is known that the peak of zooplankton development is shifted by 10-15 days from the beginning of the active vegetation of phytoplankton [44]. In our study (in the northern regions of the Barents Sea), we were unable to trace the mutual influence of phyto- and zoo-plankton, since low concentrations of chlorophyll- $a$ indicated that the mass phytoplankton bloom in the ice edge region in 2016 and 2019 had not yet begun, and in 2018 it was only in the initial stage. That indicates that there was no food supply to provide the zooplankton community peak of development at the time of our research.

The species composition of microalgae developing in spring in Atlantic and Arctic waters is identical. First of all, this is true for the dominant species, i.e., diatoms that are the base of the spring phytoplankton community. However, despite the high similarity of the phytoplankton species composition, there is a difference in the timing of the onset of the active reproduction, the onset of the spring bloom maximum and the levels of its numerical expression in waters of different origin [38]. The discrepancy between these parameters in Atlantic and Barents waters depends to a greater extent on the geographic origin of the water masses and the processes altering the main oceanographic characteristics that affect the change in biological seasons in the Barents Sea. The greatest role in this process belongs to the timing of the formation and destruction of the water mass vertical density stratification. The latter in Arctic water masses evolves as a result of the sea ice melting and in Atlantic water masses it is caused by warming of the upper water layer, which is why the timing of the phases of the seasonal succession turns out to be shifted [45]. Barents Sea open-water phytoplankton is known to produce one spring maximum and gradually decrease its numbers as the water masses become stratified. The beginning, timing, and intensity of the phytoplankton bloom in the Barents Sea are controlled by the variability in solar radiation and nutrients associated with seasonal changes in hydrological factors of water masses [46]. The end of the spring stage of the phytoplankton development and intensive sporulation in neritic species from spring populations occur in Atlantic waters in early June and in Arctic waters in late May. At the same time, the Arctic waters differ from the Atlantic ones not only in a higher abundance growth rate but in its sharper decline as well. The main reason for this phenomenon, as pointed out in [38], is the higher location of the pycnocline and the smaller vertical dimension of the habitat in Arctic waters than those in Atlantic waters, which means a faster consumption of nutrients, while in Atlantic waters the biotope is more extended vertically.

Fluctuations in the chlorophyll content in the studied water areas did not depend on the phases of the successional development of the phytoplankton community, since in the periods under study it was always at one and the same stage, i.e., the early-spring phase. The starting phase of the spring bloom, as a rule, is shaped by a relatively homogeneous composition of microalgae consisting mainly of diatoms. It is dominated by a few species that may replace each other between years. As a whole, the species composition of the microalgae community in the Marginal Ice Zone is relatively stable during spring, exhibiting a characteristic set of dominants $[17,47]$. During our investigations, diatoms characteristic 
of this particular season totally dominated. Only two species, Thalassiosira antarctica and Porosira glacialis, were registered throughout the observation period and produced high biomass levels. These species are characteristic for near-ice areas and do not belong to common cryophiles vegetating in ice. They start proliferating already under the ice as soon as the snow cover melts. There is a close relationship between the timing of their bloom and the sea ice melt $[48,49]$. The genera Chaetoceros, Navicula, and Pseudo-nitzschia demonstrated very poor species diversity and biomass levels. Although all these taxa may be presented by a large number of species ( 3 to 8 ) at the peak of the bloom and each of them can produce high abundance levels. An analysis of the abundance and biomass of phytoplankton assemblages for the years under consideration showed the presence of high biomass levels in 2018. We associate this with later dates (by 2 weeks) of the observation period in 2018 than in 2016 and 2019. In our opinion, this suggests that the phytoplankton community in 2018 was in a more active phase of the spring bloom than the communities in 2016 and 2019. We observed an almost complete absence of the algae belonging to the obligate ice algal flora, common for the ice-edge community, in surface seawater horizons of the studied area [49]. No entry of sympagic algae into the pelagic suggests that active sea ice melting had not yet begun. This is consistent with the acquired hydrological data that indicate the missing ice melt in 2016 and 2019 and initial processes of the ice melt in the easternmost transect in 2018. Thus, it can be asserted that in waters under investigation the phytoplankton community was in a state corresponding to the early-spring stage of the arctic pelagic open-water phytoplankton successional cycle and had not yet reached the bloom peak [47].

The research carried out is important for monitoring possible ecosystem changes happening in Arctic marine ecosystems under the influence of global biospheric processes. The general warming of the climate observed since the early 1980s [50] and a long-term anthropogenic burden render the Arctic ecosystems especially vulnerable. The impact of these factors can lead to the restructuring of the lower link of the pelagic ecosystem, i.e., the structure of phytoplankton communities and their productivity, which will inevitably affect both all links of the ecosystem and the entire trophic structure of the ocean [51,52].

\section{Conclusions}

Long-term investigations of chlorophyll- $a$ content in the pelagic zone of the Barents Sea during spring covered seawater areas located at high latitudes north of $75^{\circ} \mathrm{N}$ experiencing the influence of the sea ice edge and the Polar Frontal Zone.

During all of the cruises, microalgae communities appeared to be in a state of an early-spring phase of the annual successional cycle. An analysis of the dominant sets of microalgae has suggested an inter-annual stability in the taxonomic composition of pelagic microalgae during spring.

In April, the phytoplankton community in the Marginal Ice Zone does not reach the spring bloom maximum, which is confirmed by both low chlorophyll and biomass levels and the specific species composition of the community. This is tied to and thus may be caused by the absence of sea-ice melting making it impossible for significant biomasses of sympagic algae to be released into the pelagic.

Increased values of the chlorophyll concentration were recorded in the vicinity of the ice edge. This pattern can be traced along the entire Marginal Ice Zone.

The Polar Front appeared to be a substantial factor affecting the distribution and concentration of chlorophyll- $a$ during the investigations. The Polar Front acts as a powerful boundary dividing water masses with different quantitative parameters of chlorophyll. The front separated the more productive Arctic waters with chlorophyll concentrations on average 1-5 mg/ $\mathrm{m}^{3}$ from Atlantic waters where chlorophyll content was an order of magnitude lower. The Near-Edge Front also divided water masses with different chlorophyll content, but it had lesser effect on the distribution of chlorophyll- $a$. However, the concentration of chlorophyll- $a$ in Arctic waters exceeded that in waters of other origin (Atlantic or Barents Sea waters) no more than by a factor of 2 . 
There is a strong need for further research on microalgal communities in the Arctic. The data obtained during the given studies can be used as a background to predict possible changes in the ecosystem of the Arctic under the influence of man-caused and natural processes.

Author Contributions: Conceptualization, P.R.M.; methodology, P.R.M.; formal analysis, V.V.V. and A.S.B., investigation, V.V.V. and A.S.B.; data curation, V.V.V.; visualization, A.S.B.; writing-original draft preparation, P.R.M., V.V.V. and A.S.B. All authors have read and agreed to the published version of the manuscript.

Funding: This study was funded by the Ministry of Science and Higher Education of the Russian Federation.

Institutional Review Board Statement: Not applicable.

Informed Consent Statement: Not applicable.

Data Availability Statement: The data are available on request from the corresponding author.

Acknowledgments: We thank the personnel of the Plankton Laboratory at the Murmansk Marine Biological Institute for their aid in the collection and processing of water samples.

Conflicts of Interest: The authors declare no conflict of interest.

\section{Appendix A}
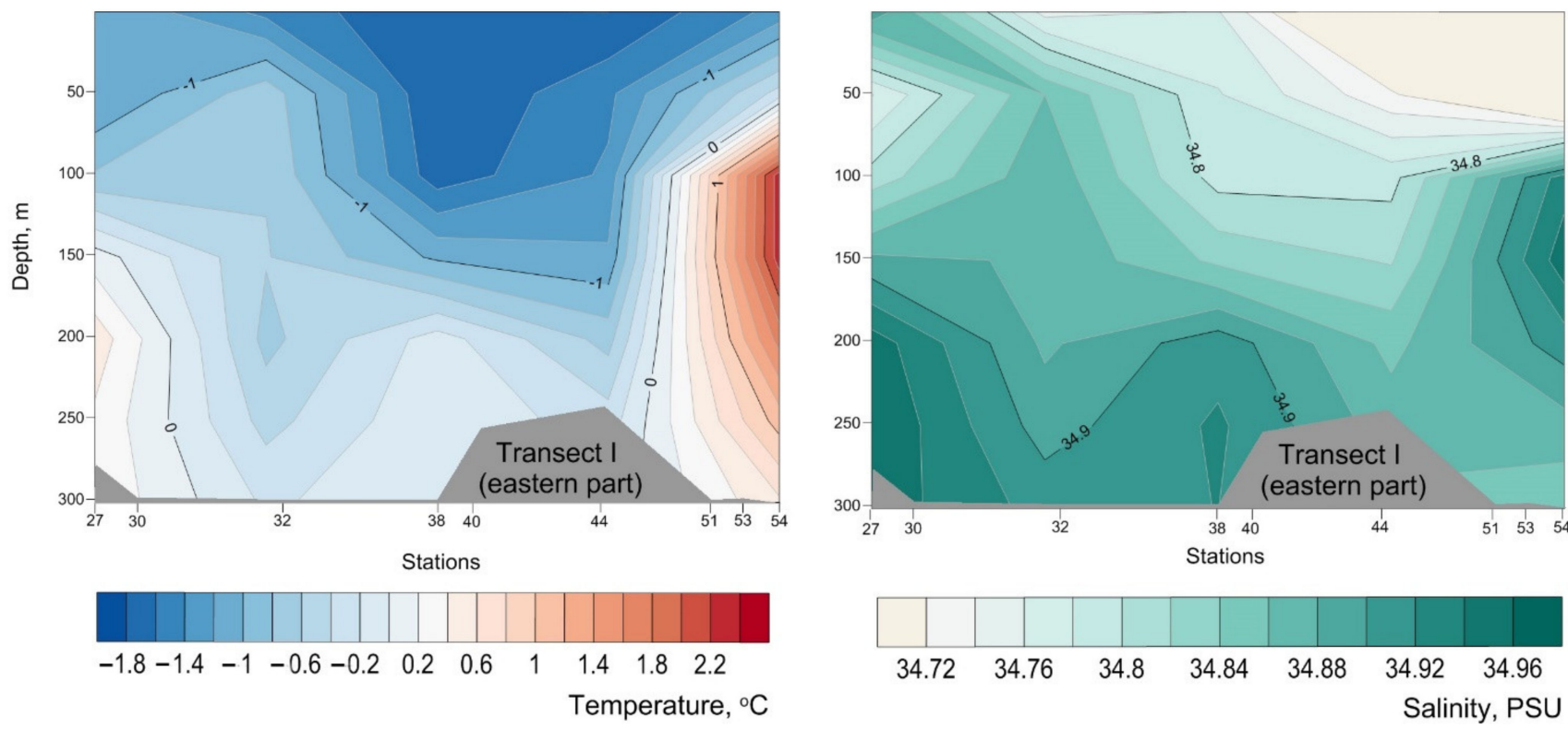

Figure A1. T $\left({ }^{\circ} \mathrm{C}\right)$ and S (PSU) at Transect I (eastern part), 2016. 

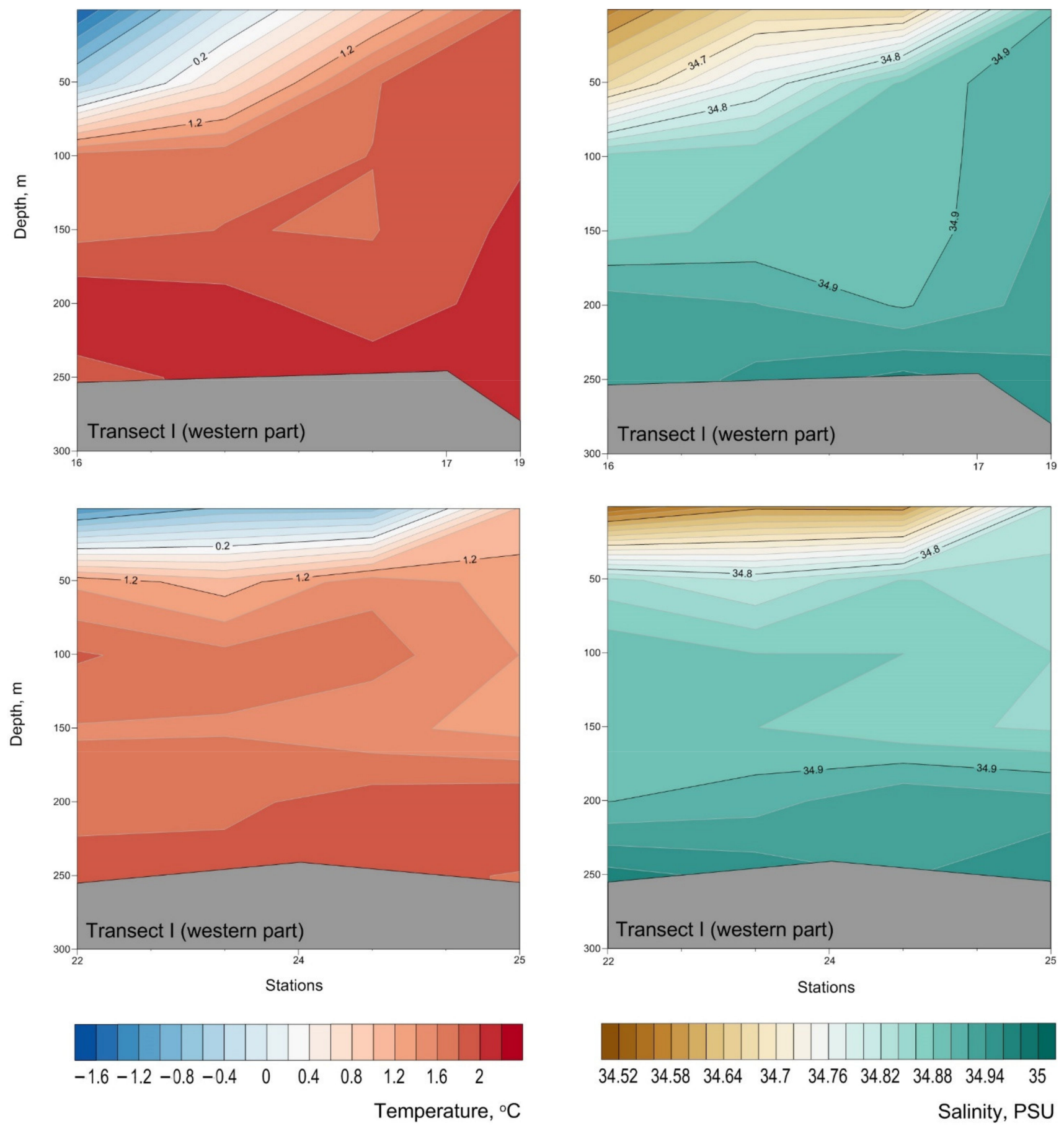

Figure A2. T $\left({ }^{\circ} \mathrm{C}\right)$ and S (PSU) at Transect I (western part), 2016. 

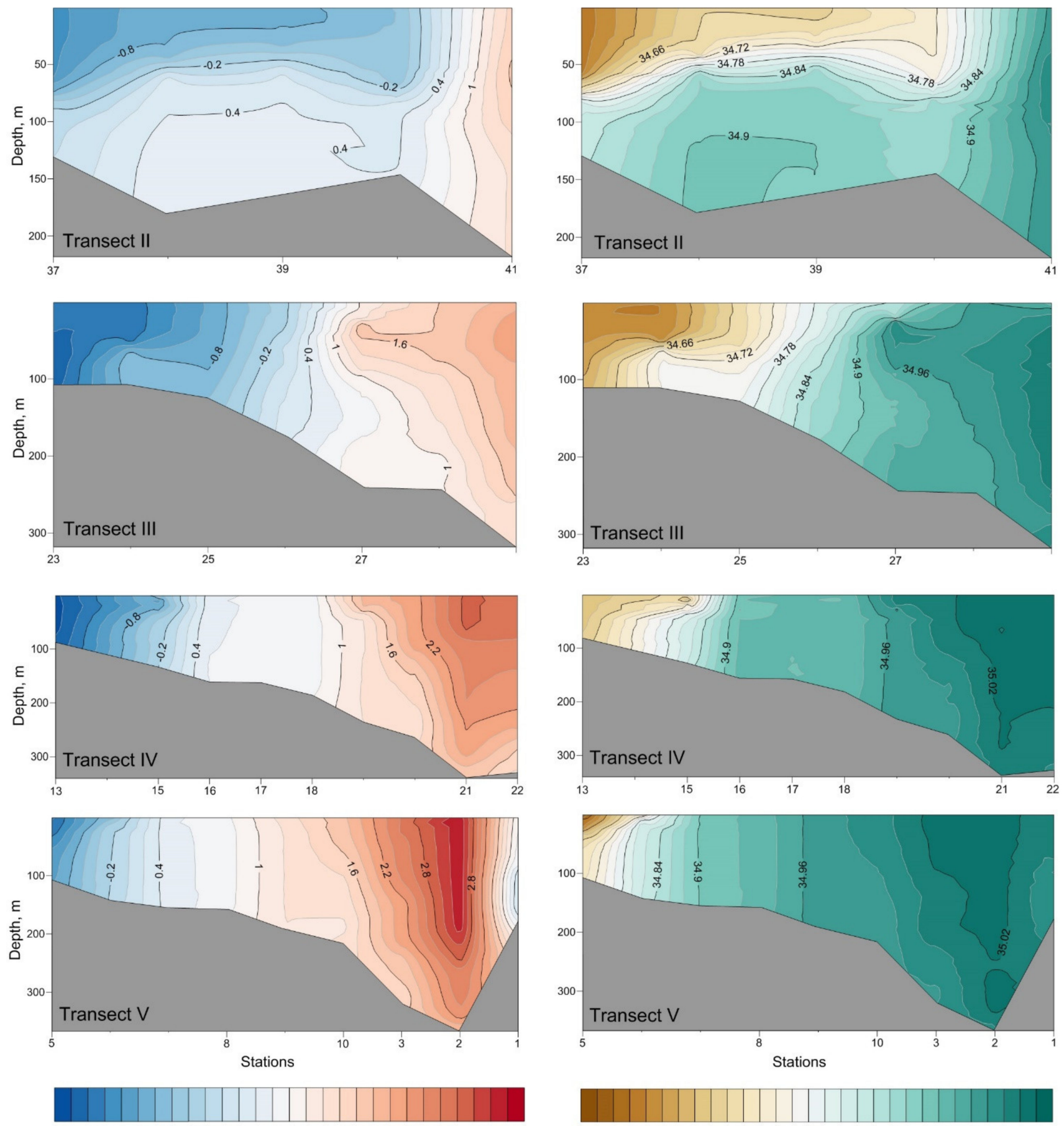

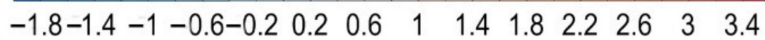

Temperature, ${ }^{\circ} \mathrm{C}$

$34.5 \quad 34.56 \quad 34.6234 .6834 .74 \quad 34.8 \quad 34.8634 .92 \quad 34.98 \quad 35.04$

Salinity, PSU

Figure A3. T $\left({ }^{\circ} \mathrm{C}\right)$ and S (PSU) at Transects II, III, IV and V, 2018. 

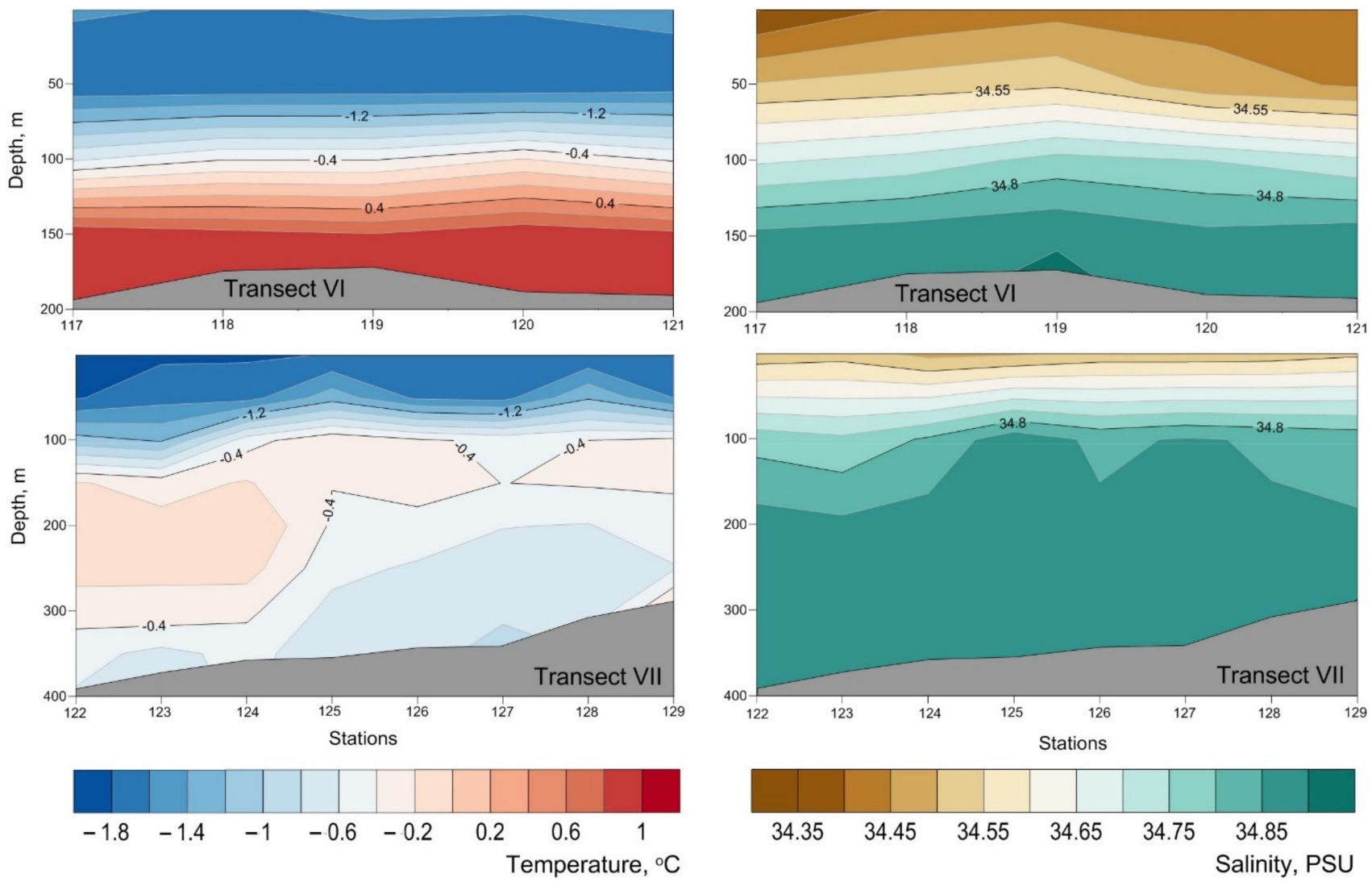

Figure A4. T $\left({ }^{\circ} \mathrm{C}\right)$ and S (PSU) at Transects VI and VII, 2018.
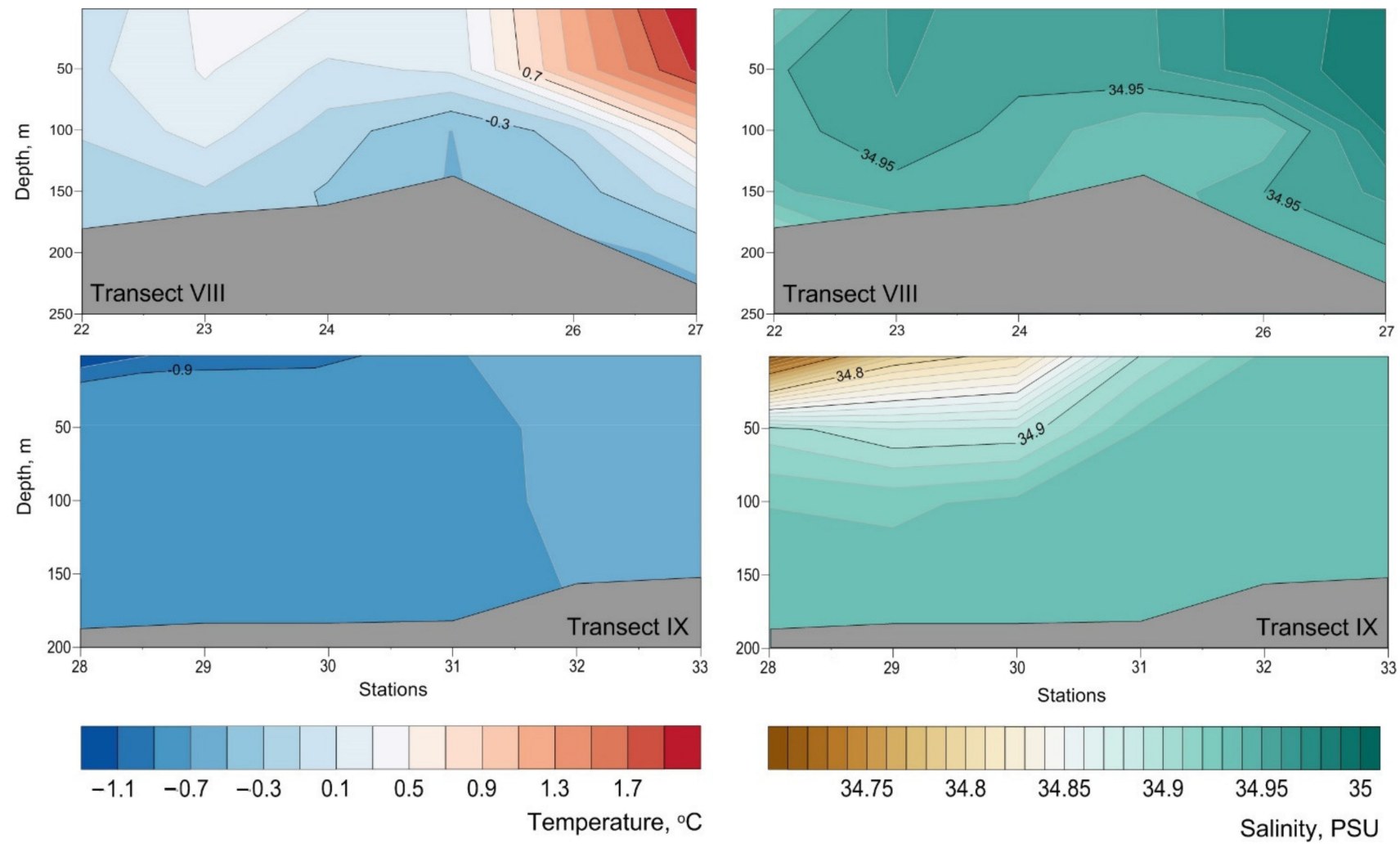

Figure A5. T $\left({ }^{\circ} \mathrm{C}\right)$ and S (PSU) at Transects VIII and IX, 2019. 

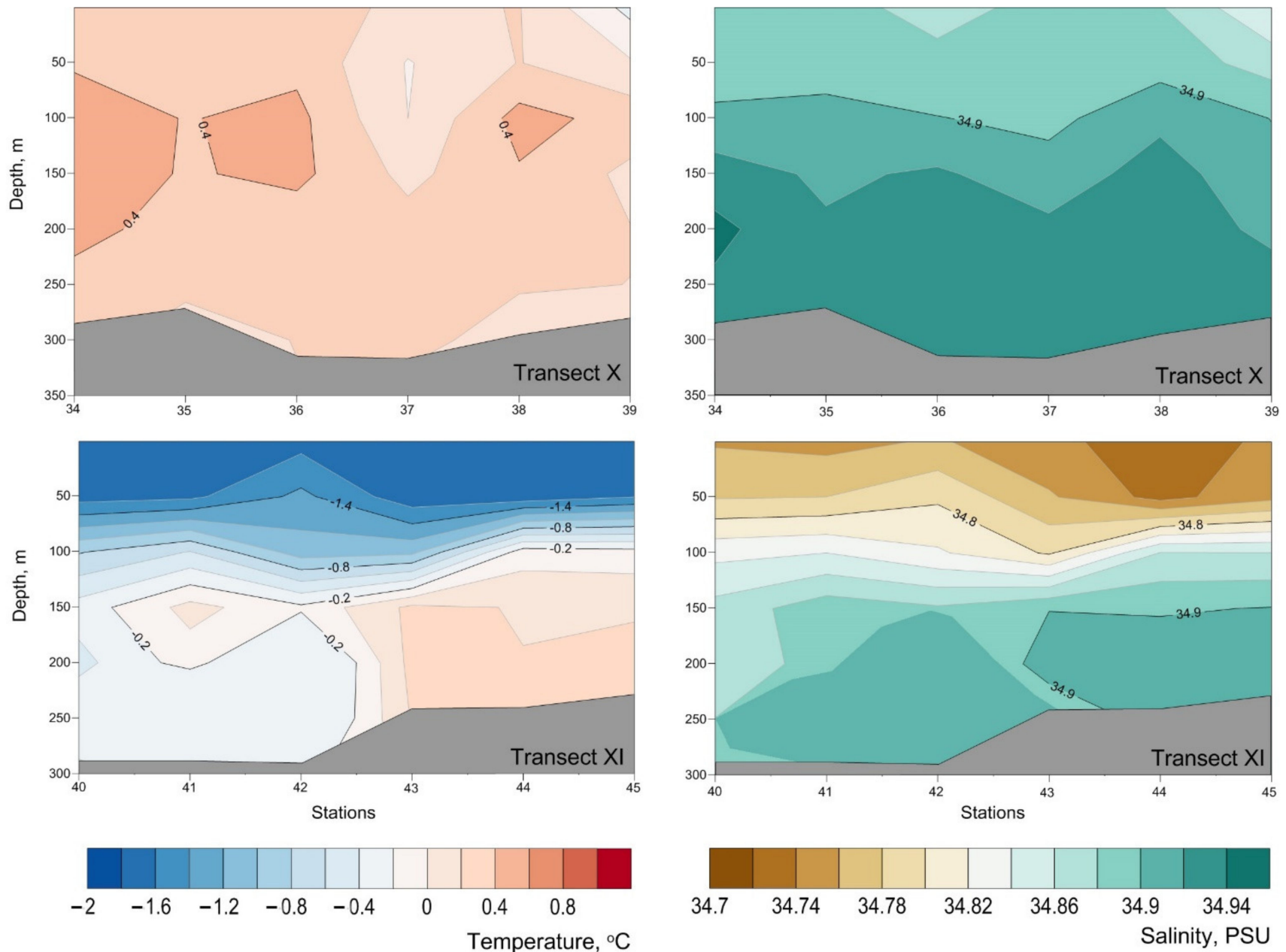

Figure A6. T $\left({ }^{\circ} \mathrm{C}\right)$ and S (PSU) at Transects X and XI, 2019.

\section{Appendix B}

Table A1. Concentrations of chlorophyll- $a(\mathrm{Chl}-a)$ and hydrological conditions at the investigated transects.

\begin{tabular}{|c|c|c|c|c|c|c|c|c|}
\hline \multirow{2}{*}{ Water Masses } & \multirow{2}{*}{ St. } & \multirow{2}{*}{ Date } & \multirow{2}{*}{ Coordinates } & \multirow{2}{*}{$\begin{array}{c}\text { Total } \\
\text { Depth (m) }\end{array}$} & \multicolumn{4}{|c|}{ Chl- $a\left(\mathrm{mg} / \mathrm{m}^{3}\right)$ at Depth (m) } \\
\hline & & & & & 0 & 10 & 25 & 50 \\
\hline \multicolumn{9}{|c|}{ Transect I (Ice-edge/Near-Edge Frontal Zone) } \\
\hline \multirow[t]{12}{*}{ Arctic water } & 16 & 12 April 2016 & $76^{\circ} 26^{\prime} \mathrm{N}, 33^{\circ} 42^{\prime} \mathrm{E}$ & 254 & 0.69 & 0.77 & 0.79 & 0.60 \\
\hline & 22 & 14 April 2016 & $76^{\circ} 12^{\prime} \mathrm{N}, 38^{\circ} 57^{\prime} \mathrm{E}$ & 252 & 0.93 & 0.83 & 0.60 & 0.32 \\
\hline & 24 & 14 April 2016 & $76^{\circ} 10^{\prime} \mathrm{N}, 39^{\circ} 00^{\prime} \mathrm{E}$ & 244 & 0.59 & 0.62 & 0.22 & 0.39 \\
\hline & 27 & 16 April 2016 & $78^{\circ} 13^{\prime} \mathrm{N}, 43^{\circ} 56^{\prime} \mathrm{E}$ & 281 & 0.34 & 0.59 & 0.38 & 0.33 \\
\hline & 30 & 16 April 2016 & $78^{\circ} 05^{\prime} \mathrm{N}, 43^{\circ} 53^{\prime} \mathrm{E}$ & 311 & 0.30 & 0.29 & 0.47 & 0.35 \\
\hline & 32 & 17 April 2016 & $78^{\circ} 09^{\prime} \mathrm{N}, 49^{\circ} 04^{\prime} \mathrm{E}$ & 300 & 0.36 & 0.42 & 0.31 & 0.23 \\
\hline & 38 & 20 April 2016 & $78^{\circ} 32^{\prime} \mathrm{N}, 54^{\circ} 04^{\prime} \mathrm{E}$ & 300 & 0.49 & 0.50 & 0.54 & 0.34 \\
\hline & 40 & 20 April 2016 & $78^{\circ} 26^{\prime} \mathrm{N}, 54^{\circ} 04^{\prime} \mathrm{E}$ & 259 & 0.46 & 0.76 & 0.79 & 0.38 \\
\hline & 44 & 21 April 2016 & $78^{\circ} 29^{\prime} \mathrm{N}, 54^{\circ} 04^{\prime} \mathrm{E}$ & 260 & 0.77 & 0.84 & 0.78 & 0.51 \\
\hline & 51 & 25 April 2016 & $79^{\circ} 15^{\prime} \mathrm{N}, 64^{\circ} 11^{\prime} \mathrm{E}$ & 300 & 0.70 & 0.51 & 0.45 & 0.63 \\
\hline & 53 & 26 April 2016 & $79^{\circ} 12^{\prime} \mathrm{N}, 64^{\circ} 09^{\prime} \mathrm{E}$ & 302 & 0.44 & 0.54 & 0.58 & 0.45 \\
\hline & 54 & 26 April 2016 & $79^{\circ} 10^{\prime} \mathrm{N}, 64^{\circ} 11^{\prime} \mathrm{E}$ & 313 & 0.75 & 0.76 & 1.00 & 0.74 \\
\hline mean \pm std & & & & & $0.57 \pm 0.20$ & $0.62 \pm 0.17$ & $0.57 \pm 0.23$ & $0.44 \pm 0.15$ \\
\hline
\end{tabular}


Table A1. Cont.

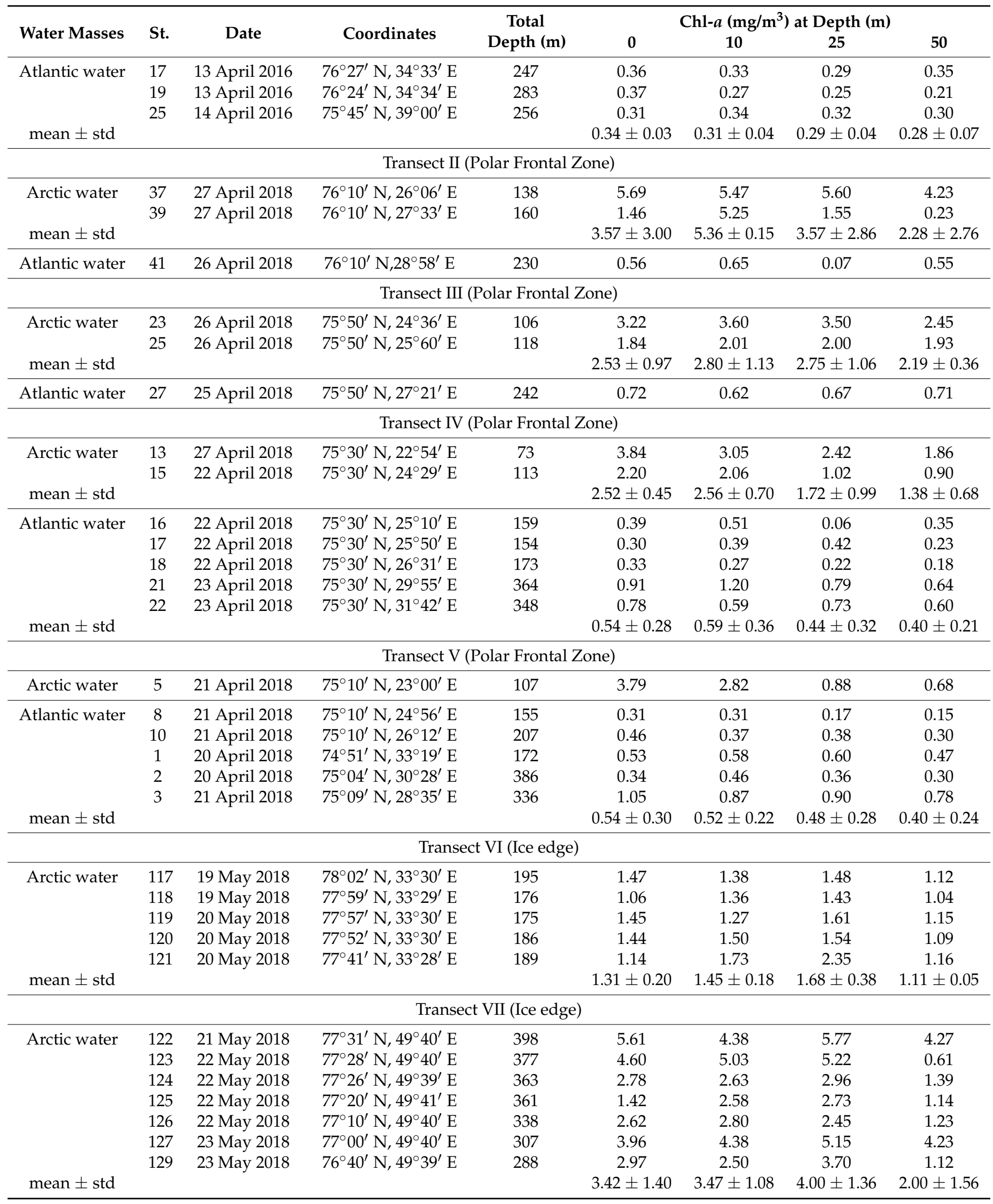


Table A1. Cont.

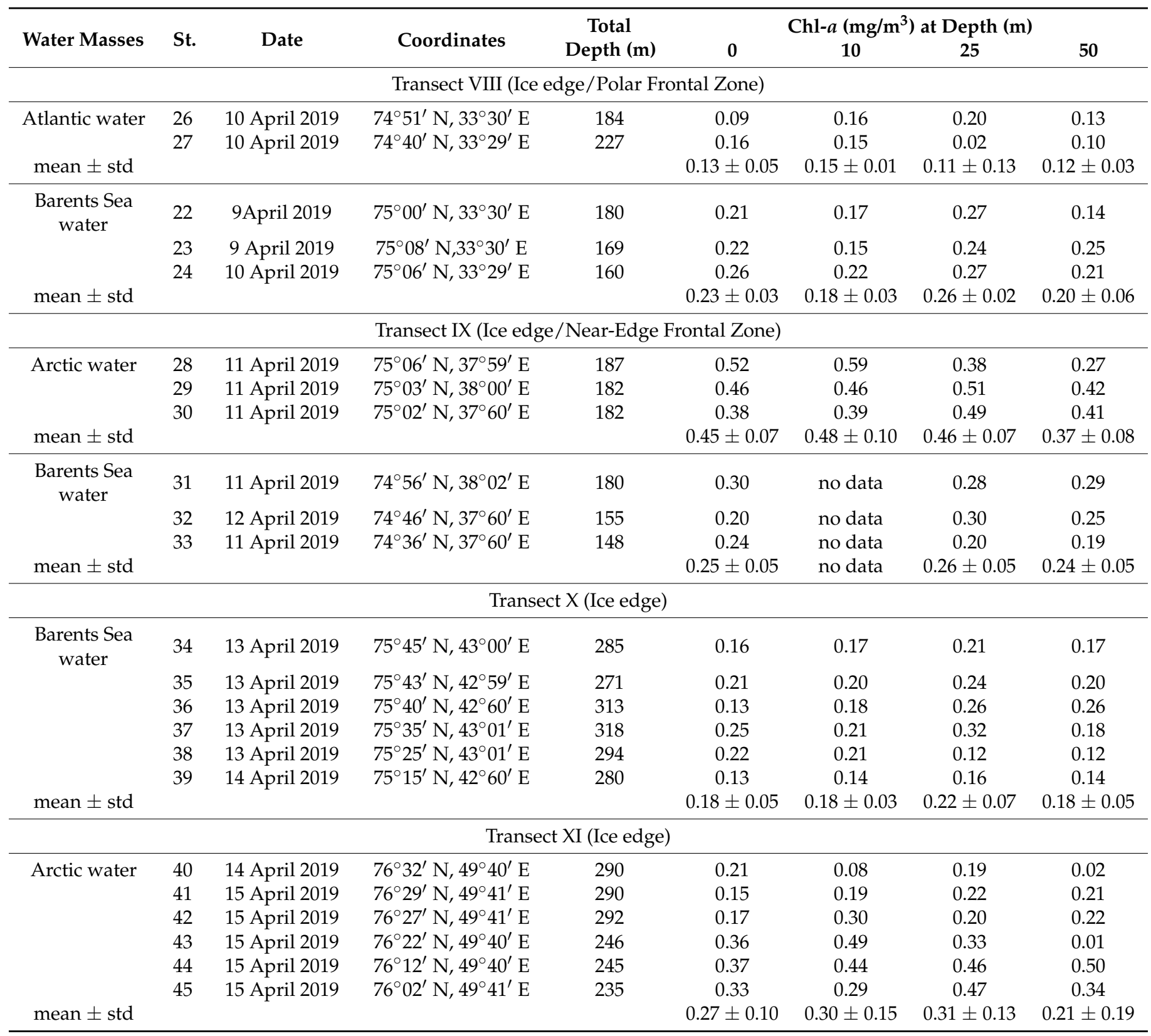




\section{Appendix C}

Table A2. Nutrient concentrations averaged for the stations and seawater horizons in the Barents Sea Marginal Ice Zone in April and May 2018.

\begin{tabular}{|c|c|c|c|c|c|c|c|c|}
\hline \multicolumn{9}{|c|}{ Depth (m) } \\
\hline & \multicolumn{2}{|c|}{0} & \multicolumn{2}{|c|}{25} & \multicolumn{2}{|c|}{50} & \multicolumn{2}{|c|}{100} \\
\hline & $\min$ & $\max$ & $\min$ & $\max$ & $\min$ & $\max$ & $\min$ & $\max$ \\
\hline \multicolumn{9}{|c|}{$\mathrm{P}^{-\mathrm{PO}_{4}}(\mu \mathrm{M})$} \\
\hline & 0.14 & 0.55 & 0.21 & 0.50 & 0.36 & 0.56 & 0.49 & 0.68 \\
\hline mean \pm std & \multicolumn{2}{|c|}{$0.37 \pm 0.12$} & \multicolumn{2}{|c|}{$0.33 \pm 0.08$} & \multicolumn{2}{|c|}{$0.46 \pm 0.13$} & \multicolumn{2}{|c|}{$0.60 \pm 0.05$} \\
\hline \multicolumn{9}{|c|}{$\mathrm{N}-\mathrm{NO}_{3}(\mu \mathrm{M})$} \\
\hline & 1.84 & 15.53 & 0.53 & 13.81 & 0.94 & 15.08 & 8.24 & 18.98 \\
\hline mean \pm std & \multicolumn{2}{|c|}{$8.99 \pm 3.24$} & \multicolumn{2}{|c|}{$7.14 \pm 4.21$} & \multicolumn{2}{|c|}{$7.09 \pm 3.46$} & \multicolumn{2}{|c|}{$13.59 \pm 2.54$} \\
\hline
\end{tabular}

Table A3. Nutrient concentrations averaged for the stations and seawater horizons in the Barents Sea Marginal Ice Zone in April 2019.

\begin{tabular}{|c|c|c|c|c|c|c|c|c|}
\hline \multicolumn{9}{|c|}{ Depth (m) } \\
\hline & \multicolumn{2}{|c|}{0} & \multicolumn{2}{|c|}{25} & \multicolumn{2}{|c|}{50} & \multicolumn{2}{|c|}{100} \\
\hline & $\min$ & $\max$ & $\min$ & $\max$ & $\min$ & $\max$ & $\min$ & $\max$ \\
\hline \multicolumn{9}{|c|}{$\mathrm{P}^{-\mathrm{PO}_{4}}(\mu \mathrm{M})$} \\
\hline & 0.43 & 0.85 & 0.31 & 0.59 & 0.43 & 0.70 & 0.41 & 0.81 \\
\hline mean \pm std & \multicolumn{2}{|c|}{$0.58 \pm 0.05$} & \multicolumn{2}{|c|}{$0.46 \pm 0.04$} & \multicolumn{2}{|c|}{$0.60 \pm 0.04$} & \multicolumn{2}{|c|}{$0.58 \pm 0.04$} \\
\hline \multicolumn{9}{|c|}{$\mathrm{N}-\mathrm{NO}_{3}(\mu \mathrm{M})$} \\
\hline & 4.63 & 12.01 & 2.18 & 10.26 & 1.53 & 10.98 & 4.83 & 11.81 \\
\hline mean \pm std & \multicolumn{2}{|c|}{$9.83 \pm 0.95$} & \multicolumn{2}{|c|}{$7.24 \pm 1.25$} & \multicolumn{2}{|c|}{$8.20 \pm 1.39$} & \multicolumn{2}{|c|}{$8.79 \pm 1.03$} \\
\hline
\end{tabular}

\section{References}

1. Lien, V.S.; Trofimov, A.G. Formation of Barents Sea Branch Water in the north-eastern Barents Sea. Polar Res. 2013, $32,18905$. [CrossRef]

2. Rudels, B.; Anderson, L.G.; Jones, E.P. Formation and evolution of the surface mixed layer and halocline of the Arctic Ocean. J. Geophys. Res. 1996, 101, 8807-8821. [CrossRef]

3. Averkiev, A.S. Transformation of Atlantic water masses in the Barents, Kara and Laptev Sea by observation data in september 2014 year. Int. Res. J. 2017, 7, 37-41. [CrossRef]

4. Kazmin, A.S. Structure and Variability of Oceanic Frontal Zones: Analysis of Global Satellite Information. Ph.D. Dissertation, Science, IO RAS, Moscow, Russia, 2014; p. 43.

5. Ivshin, V.; Trofimov, A.; Titov, O. Barents Sea thermal frontal zones in 1960-2017: Variability, weakening, shifting. Ices J. Mar. Sci. 2019, 76, 13-19. [CrossRef]

6. Kostianoy, A.G.; Nihoul, J.C.J.; Rodionov, V.B. Physical Oceanography of Frontal Zones in the Subarctic Seas. Elsevier Oceanogr. Ser. 2004, 71, 5-8. [CrossRef]

7. Sergeeva, V.M.; Mosharov, S.A.; Nedospasov, A.A.; Polukhin, A.A. Phytoplankton community structure in the polar front of the Eastern Barents Sea at the end of the growth season. Oceanology 2018, 58, 700-709. [CrossRef]

8. Monaco, A.; Prouzet, P. Biodiversity of Phytoplankton: Responses to Environmental Changes in Coastal Zones. In Marine Ecosystems; Wiley\&Sons, Inc.: Hoboken, NJ, USA, 2015; pp. 25-80. [CrossRef]

9. Benedetti, F.; Vogt, M.; Elizondo, U.H.; Righetti, D.; Zimmermann, N.E.; Gruber, N. Major restructuring of marine plankton assemblages under global warming. Nat. Commun. 2021, 12, 5226. [CrossRef]

10. Perrette, M.; Yool, A.; Quartly, G.; Popova, E. Near-ubiquity of ice-edge blooms in the Arctic. Biogeosciences 2011, 8, 515-524. [CrossRef]

11. Dong, K.; Kvile, Ø.K.; Stenseth, N.C.; Stige, L.C. Associations among temperature, sea ice and phytoplankton bloom dynamics in the Barents Sea. Mar. Ecol. Prog. Ser. 2020, 635, 25-36. [CrossRef]

12. Engelsen, O.; Hegseth, E.; Hop, H.; Hansen, E.; Falk-Petersen, S. Spatial variability of chlorophyll-a in the marginal ice zone of the Barents Sea, with relations to sea ice and oceanographic conditions. J. Mar. Syst. 2002, 35, 79-97. [CrossRef] 
13. Hodal, H.; Kristiansen, S. The importance of small-celled phytoplankton in spring bloomsat the marginal ice zone in the northern Barents Sea. Deep Sea Res. 2008, 55, 2176-2185. [CrossRef]

14. Reigstad, M.; Wassmann, P.; Riser, C.; Øygarden, S.; Rey, F. Variations in hydrography, nutrients and chlorophyll $a$ in the marginal ice-zone and the central Barents Sea. J. Mar. Syst. 2002, 38, 9-29. [CrossRef]

15. Wassmann, P.; Ratkova, T.; Andreassen, I.; Vernet, M.; Pedersen, G.; Rey, F. Spring bloom development in the marginal ice zone and the central Barents Sea. Mar. Ecol. 1999, 20, 321-346. [CrossRef]

16. Sturluson, M.; Nielsen, T.; Wassmann, P. Bacterial abundance, biomass and production duringspring blooms in the northern Barents Sea. Deep Sea Res. 2008, 55, 2186-2198. [CrossRef]

17. Degerlund, M.; Eilertsen, H.C. Main Species Characteristics of Phytoplankton Spring Blooms in NE Atlantic and Arctic Waters $\left(68-80^{\circ} \mathrm{N}\right)$. Estuaries Coasts 2010, 33, 242-269. [CrossRef]

18. Wang, Y.; Xiang, P.; Kang, J.; Ye, Y.Y.; Lin, G.M.; Yang, Q.L.; Lin, M. Microphytoplankton community structure in the western Arctic Ocean: Surface layer variability of geographic and temporal considerations in summer. Hydrobiologia 2018, 811, 295-312. [CrossRef]

19. Johnsen, G.; Norli, M.; Moline, M.; Robbins, I.; Quillfeldt, S.; Søresen, K.; Cottier, F.; Berge, J. The advective origin of an under-ice spring bloom in the Arctic Ocean using multiple observational platforms. Polar Biol. 2018, 41, 1197-1216. [CrossRef]

20. Makarevich, P.; Vodopianova, V.; Bulavina, A.; Kalinka, O. Influence of the Barents Sea Frontal zones on chlorophyll concentration in Spring. KnE Life Sci. 2020, 5, 536-546. [CrossRef]

21. Mamaev, O.I. Thermohaline Analysis of the World Ocean Waters; Hydrometeoizdat: Leningrad, Russia, 1987.

22. Ozhigin, V.; Ivshin, V.; Trofimov, A.; Karsakov, A.L.; Antsiferov, M. The Barents Sea Water: Structure, Circulation, Variability; PINRO Press: Murmansk, Russia, 2016.

23. Murphy, J.; Riley, J.P. Modified single solution method for the determination of phosphate in natural waters. Anal. Chim. Acta 1962, 27, 31-36. [CrossRef]

24. Strickland, J.D.H.; Parsons, T.R. A practical handbook of seawater analysis. In Fisheries Research Board of Canada, 2nd ed.; Watson, J., Reinhart, J.M., Cook, D.J., Eds.; Alger Press Ltd.: Ottawa, ON, Canada, 1972; p. 311.

25. Water. Spectrophotometric Determination of Chlorophyll-a (State Standard: 17.1.4.02-90); Standards: Moscow, Russia, 2001.

26. Aminot, A.; Rey, F. Standard Procedure for the Determination of Chlorophyll a by Spectroscopic Methods; International Council for the Exploration of the Sea: Copenhagen, Denmark, 2000.

27. Dodson, A.; Thomas, W. Concentrating plankton in a gentle fashion. Limnol. Oceanogr. 1964, 9, 455-456. [CrossRef]

28. Sun, J.; Liu, D. Geometric models for calculating cell biovolume and surface area for phytoplankton. J. Plankton Res. 2003, 25, 1331-1346. [CrossRef]

29. Mahotin, M.; Ivanov, V. Distribution of Atlantic water masses in the Barents Sea according to observations and numerical modeling. Proc. Hydrometeorol. Res. Cent. Russ. Fed. 2016, 361, 169-191.

30. Zimin, A.; Konik, A.; Atadzhanova, O. Quantitative estimations of the variability of characteristics of the temperature of the sea (sst) surface in the front of the frontal zone of the Barents Sea. Sch. Notes RSHU 2018, 51, 99-108.

31. Barton, B.; Lenn, Y.; Lique, C. Observed Atlantification of the Barents Sea Causes the Polar Front to Limit the Expansion of Winter Sea Ice. J. Phys. Oceanogr. 2018, 48, 1849-1866. [CrossRef]

32. Plankton of the Sea of the Western Arctic; KSC RAS Press: Apatity, Russia, 1997.

33. Zhichkin, A.P. Peculiarities of interannual and seasonal variations of the Barents Sea ice coverage anomalies. Russ. Meteorol. Hydrol. 2015, 40, 319-326. [CrossRef]

34. Dalpadado, P.; Arrigo, K.; Hjøllo, S.; Rey, F.; Ingvaldsen, R.B.; Sperfeld, E.; Dijken, G.L.; Stige, L.C.; Olsen, A.; Ottersen, G. Productivity in the Barents Sea-Response to Recent Climate Variability. PLoS ONE 2014, 9, e95273. [CrossRef]

35. Ryabchenko, V.; Gorchakov, V.; Dvornikov, A.; Pugalova, S. Estimating the effect of ice on the primary production of phytoplankton in the Barents Sea (based on three-dimensional modeling). Fundam. Prikl. Gidrofiz. 2016, 9, 41-51.

36. Lien, V.; Schlichtholz, P.; Skagseth, O.; Vikebo, F. Wind-Driven Atlantic Water Flow as a Direct Mode for Reduced Barents Sea Ice Cover. J. Clim. 2017, 30, 803-812. [CrossRef]

37. Onarheim, I.; Arthun, M. Toward an ice-free Barents Sea. Geophys. Res. Lett. 2017, 44, 8387-8395. [CrossRef]

38. Kuznetsov, L.L.; Shoshina, E.V. Phytocenoses of the Barents Sea (Physiological and Structural Characteristics); SSC RAS Publ.: Rostovon-Don, Russia, 2015.

39. Raymont, J.E.G. Plankton and Productivity in the Oceans; Pergamon Press Ltd.: Oxford, UK, 1963; p. 660. Available online: https://archive.org/details/planktonproducti0000raym/page/n7/mode/2up (accessed on 26 November 2021).

40. IPCC. IPCC Special Report on the Ocean and Cryosphere in a Changing Climate. 2019. Available online: https://www.ipcc.ch/ srocc/ (accessed on 26 November 2021).

41. Dalpadado, P.; Ingvaldsen, R.; Hassel, A. Zooplankton biomass variation in relation to climatic conditions in the Barents Sea. Polar Biol. 2003, 26, 233-241. [CrossRef]

42. Wassmann, P.; Reigstad, M.; Haug, T.; Rudels, B.; Carroll, M.L.; Hop, H.; Gabrielsen, G.W.; Falk-Petersen, S.; Denisenko, S.G.; Arashkevich, E.; et al. Food webs and carbon flux in the Barents Sea. Prog. Oceanogr. 2006, 71, 232-287. [CrossRef]

43. Dvoretsky, V.G. Zooplankton production in the Barents Sea in Summer. Izvestya TINRO 2012, 168, 169-183.

44. Eiane, K.; Tande, K.S. Meso and macrozooplankton. In Ecosystem Barents Sea; Sakshaug, E., Johnsen, G., Kovacs, K.M., Eds.; Tapir Academic Press: Trondheim, Norway, 2009; pp. 209-234. 
45. Rey, F.; Loeng, H. The influence of ice and hydrographic conditions on the development of phytoplankton in the Barents Sea. In Marine Biology of Polar Regions and Effect of Stress on Marine Organisms; Gray, J.S., Christiansen, M.E., Eds.; Wiley\&Sons Ltd.: Chichester, Great Britain, 1985; pp. 49-63. Available online: https://archive.org/details/marinebiologyofp0000euro/page/n7 /mode/2up (accessed on 26 November 2021).

46. Signorini, S.R.; McClain, C.R. Environmental factors controlling the Barents Sea spring-summer phytoplankton blooms. Geophys. Res. 2009, 36, 1-5. [CrossRef]

47. Makarevich, P.R.; Druzhkova, E.I.; Larionov, V.V. Primary producers of the Barents Sea. In Diversity of Ecosystems; Mahamane, A., Ed.; InTech Open: Rijeka, Croatia, 2012; pp. 367-393. Available online: http://www.intechopen.com/ books / diversity-of-ecosystems/primary-producers-of-the-barents-sea (accessed on 26 November 2021).

48. Palmisano, A.C.; Garrison, D.L. Microorganisms in Antarctic sea ice. In Antarctic Microbiology; Friedman, E.I., Ed.; Wiley-Liss: New York, NY, USA, 1993; pp. 167-218.

49. Poulin, M.; Daugbjerg, N.; Gradinger, R.; Ilyash, L.; Ratkova, T.; Quillfeldt, S. The pan-Arctic biodiversity of marine pelagic and sea-ice unicellular eukaryotes: A first-attempt assessment. Mar. Biodivers. 2011, 41, 13-28. [CrossRef]

50. Fujiwara, A.; Hirawake, T.; Suzuki, K.; Imai, I.; Saitoh, S.I. Timing of sea ice retreat can alter phytoplankton community structure in the western Arctic Ocean. Biogeosciences 2014, 11, 1705-1716. [CrossRef]

51. Park, J.; Kug, J.; Bader, J. Amplified Arctic warming by phytoplankton under greenhouse warming. Proc. Natl. Acad. Sci. USA 2015, 112, 5921-5926. [CrossRef]

52. Ardyna, M.; Arrigo, K. Phytoplankton dynamics in a changing Arctic Ocean. Nat. Clim. Change 2020, 10, 892-903. [CrossRef] 